\title{
Arbeidsmarktrelevantie studie onderwijswetenschappen
}

Citation for published version (APA):

de Grip, A., \& van der Velden, R. K. W. (1999). Arbeidsmarktrelevantie studie onderwijswetenschappen. Researchcentrum voor Onderwijs en Arbeidsmarkt, Faculteit der Economische Wetenschappen. ROA Working Papers No. 6 https://doi.org/10.26481/umarow.1999006

Document status and date:

Published: 01/01/1999

DOI:

10.26481/umarow.1999006

Document Version:

Publisher's PDF, also known as Version of record

\section{Please check the document version of this publication:}

- A submitted manuscript is the version of the article upon submission and before peer-review. There can be important differences between the submitted version and the official published version of record.

People interested in the research are advised to contact the author for the final version of the publication, or visit the DOI to the publisher's website.

- The final author version and the galley proof are versions of the publication after peer review.

- The final published version features the final layout of the paper including the volume, issue and page numbers.

Link to publication

\footnotetext{
General rights rights.

- You may freely distribute the URL identifying the publication in the public portal. please follow below link for the End User Agreement:

www.umlib.nl/taverne-license

Take down policy

If you believe that this document breaches copyright please contact us at:

repository@maastrichtuniversity.nl

providing details and we will investigate your claim.
}

Copyright and moral rights for the publications made accessible in the public portal are retained by the authors and/or other copyright owners and it is a condition of accessing publications that users recognise and abide by the legal requirements associated with these

- Users may download and print one copy of any publication from the public portal for the purpose of private study or research.

- You may not further distribute the material or use it for any profit-making activity or commercial gain

If the publication is distributed under the terms of Article $25 \mathrm{fa}$ of the Dutch Copyright Act, indicated by the "Taverne" license above, 


\title{
Arbeidsmarktrelevantie studie onderwijswetenschappen
}

\author{
ROA-W-1999/6
}

A. de Grip en R.K.W. van der Velden

Researchcentrum voor Onderwijs en Arbeidsmarkt

Faculteit der Economische Wetenschappen en Bedrijfskunde Universiteit Maastricht

Maastricht, september 1999 
ISBN 90-5321-282-5

SEC99.122/RvdV 


\section{Inhoud}

Bladzijde

Management summary

1 Inleiding

1.1 Achtergrond

1.2 Profiel van de studie Onderwijswetenschappen

1.3 Opzet

1.4 Leeswijzer

2 Ontwikkelingen in het initieel onderwijs 3

2.1 Primair onderwijs 3

2.2 Voortgezet onderwijs 4

2.3 BVE

2.4 Hoger Onderwijs $\quad 7$

2.5 ICT 9

2.6 Ontwikkelingen in de beroepsgroep van leerkrachten 12

3 Ontwikkelingen in het niet-initiële onderwijs 14

3.1 Oorzaken van de toenemende betekenis van het niet-initieel onderwijs $\quad 14$

3.2 Toename scholingsparticipatie $\quad 17$

3.3 Verschuivingen in de markt voor niet-initieel onderwijs 18

$\begin{array}{ll}3.4 \text { Conclusies } & 23\end{array}$

4 Verkenning van de arbeidsmarkt voor onderwijskundigen 23

4.1 De huidige arbeidsmarktsituatie $\quad 23$

4.2 Toekomstige ontwikkelingen $\quad 26$

5 Het perspectief van een nieuwe opleiding onderwijskunde 28

Bijlage 1 Lijst van gesprekspartners 33

Bijlage 2 Geschatte ontwikkeling van de instroom en uitstroom bij onderwijskunde in de periode 1993-2002

Bijlage 3 Ontwikkeling aantal eerstejaars psychologie 



\section{Management summary}

\section{Opzet}

De Universiteit Maastricht heeft het Researchcentrum voor Onderwijs en Arbeidsmarkt (ROA) gevraagd een verkennende studie uit te voeren naar de arbeidsmarktrelevantie van een nieuwe opleiding Onderwijswetenschappen. In de studie is gebruik gemaakt van deskresearch en zijn gesprekken gevoerd met sleutelinformanten uit het werkveld voor onderwijskundigen.

De verkennende studie belicht een aantal specifieke ontwikkelingen in het initieel en nietinitieel onderwijs die consequenties zullen hebben voor de vraag naar onderwijskundigen. Voor het initiële onderwijs is een beschrijving gegeven van de belangrijkste beleidsmatige ontwikkelingen in de onderwijssectoren, alsmede van sector-overschrijdende ontwikkelingen als de invoering van informatie- en communicatietechnologie (ICT) en de professionele ontwikkeling van de beroepsgroep van leerkrachten. Voor het niet-initiële onderwijs is een verkenning gemaakt van zowel de ontwikkelingen binnen de traditionele markten voor scholing, als de ontwikkeling naar nieuwe institutionele vormen waarbinnen scholingsvraagstukken worden aangepakt.

Daarnaast wordt een algemeen beeld geschetst van de arbeidsmarkt voor onderwijskundigen. Omdat specifieke gegevens over de ontwikkelingen in vraag en aanbod van onderwijskundigen vooralsnog ontbreken, heeft deze beschrijving een meer globaal karakter en dient ze vooral om een kader te geven waarbinnen de ontwikkelingen in het werkveld voor onderwijskundigen geplaatst kunnen worden.

\section{Ontwikkelingen in het werkveld voor onderwijskundigen}

In het initieel en niet-initieel onderwijs vindt een aantal ontwikkelingen plaats die belangrijke gevolgen hebben voor de vraag naar onderwijskundigen. Gemeenschappelijke elementen hierin zijn:

C verschuiving van een leerstofgerichte benadering naar een benadering waarin de competenties van leerlingen centraal staan;

C veranderende rol van de docent van leider naar begeleider van onderwijsprocessen;

C sterkere gerichtheid op de beroepspraktijk met nadrukkelijke aandacht voor sleutelkwalificaties;

C toenemende flexibiliteit, differentiatie en maatwerk in het onderwijsleerproces;

$C$ toenemend belang van ICT in het onderwijsleerproces;

C toenemende professionalisering van de beroepsgroep van leerkrachten;

$C$ toenemend belang van levenslang leren en een hiermee samenhangende groei van de scholingsparticipatie. 


\section{Vereiste competenties voor onderwijskundigen}

De bovengeschetste ontwikkelingen doen naar verwachting een groot beroep op onderwijskundige ondersteuning. Belangrijke competenties waarover onderwijskundigen moeten beschikken zijn:

C in staat zijn leerpsychologische modellen te hanteren gericht op competentie-ontwikkeling;

C in staat zijn nieuwe didactische concepten toe te passen in onderwijsleersituaties;

$C$ in staat zijn om ICT toe te passen in een didactisch concept;

$C$ in staat zijn opleidingen te ontwerpen voor de beroepspraktijk, zowel binnen als buiten schoolverband;

$C$ in staat zijn toetsen te ontwerpen voor het meten van (domeinspecifieke) competenties;

$C$ in staat zijn om scholingsvraagstukken te plaatsen binnen een bredere organisatorische context en in staat zijn om onderwijskundige oplossingen te implementeren.

\section{Ontwikkelingen op de arbeidsmarkt}

De huidige arbeidsmarkt voor onderwijskundigen is, net als voor de meeste andere sectoren in het hoger onderwijs, bijzonder gunstig. De werkloosheid onder pas afgestudeerden bedraagt slechts $3 \%$. Verwacht wordt dat in de nabije toekomst de vraag naar afgestudeerden nog verder zal toenemen. Tegelijkertijd kampen de opleidingen voor onderwijskunde en pedagogiek met een teruglopend aantal afgestudeerden. Gelet op de relatief hoge vraag in de pedagogische beroepen zullen hierdoor aanzienlijke knelpunten in de personeelsvoorziening kunnen gaan ontstaan.

De professionalisering van scholingsvraagstukken in het kader van het 'levenslang leren' en de onderwijskundige ontwikkelingen in het initieel onderwijs zal de vraag naar onderwijskundigen doen toenemen. Verwacht kan worden dat de vraag met name zal toenemen bij trainingsinstituten en bedrijfsopleidingen, PABO's en lerarenopleidingen, instellingen uit de onderwijsverzorgingsstructuur en educatieve uitgeverijen.

\section{Perspectieven van een nieuwe opleiding onderwijswetenschappen}

Gelet op de verwachte knelpunten op de arbeidsmarkt voor onderwijskundigen is het belangrijk om de toekomstige arbeidsmarktinstroom van onderwijskundigen te stimuleren. Om meer studenten voor een bepaalde studierichting te interesseren kan, afgezien van arbeidsmarktprikkels (relatieve beloning, loopbaanmogelijkheden, e.d.), een drietal wegen worden gevolgd:

C het vergroten van het aantal opleidingsplaatsen voor onderwijskunde;

$C$ het aanbieden van een ander opleidingsprofiel naast de bestaande profielen;

$C$ het verbreden van de doelgroep voor de opleiding.

De voorgestelde opleiding Onderwijswetenschappen kan tegen deze achtergrond beschouwd worden als een belangrijk instrument om in de toekomstige vraag naar onder- 
wijskundigen te voorzien. Gelet op bijvoorbeeld de ervaringen met de studierichting psychologie zal het starten van een nieuwe opleiding Onderwijswetenschappen in Maastricht naar verwachting de totale instroom van studenten onderwijskunde in Nederland vergroten. Hierdoor kan een bijdrage worden geleverd aan het verminderen van de tekorten aan onderwijskundigen.

Ook het profiel van de nieuwe studie lijkt in zijn algemeenheid goed te passen bij de geschetste ontwikkelingen, met name waar het de competentiegerichte benadering en de invoering van ICT betreft. In de gesprekken met deskundigen is dan ook in het algemeen het belang van een nieuwe opleiding onderwijskunde onderschreven. Als sterke punten van de voorgestelde opleiding kunnen worden beschouwd:

$C$ het probleem-gestuurd onderwijs;

C de competentiegerichte benadering;

C de gerichtheid op de professionele praktijk.

Met name de voorgestelde studierichting Continu Leren voor en in de Professionele Praktijk (CLPP) lijkt goed te passen bij de geschetste ontwikkelingen in het werkveld voor onderwijskundigen.

Een belangrijke doelgroep voor de opleiding kan gevormd worden door de professionals in het onderwijs zelf, zowel wat betreft de potentiële instroom voor de opleiding als wat betreft het object van studie in de opleiding. De nieuwe opleiding kan zich onderscheiden door het proces van professionalisering van de beroepsgroep van leerkrachten te begeleiden.

Door verschillende gesprekspartners is aangegeven dat een strikt onderscheid tussen de studierichting Continu Leren voor en in de Professionele Praktijk en de studierichting Leren en Elektronische Leeromgevingen minder wenselijk is. Vraagstukken rond onderwijs- en informatietechnologie zijn immers bij uitstek relevant voor het ontwerp van opleidingen voor de professionele praktijk zelf. Binnen de afstudeerrichting CLPP dient daarom voldoende aandacht geschonken te worden aan de betekenis van ICT voor het onderwijsleerproces.

Bij de afstudeerrichting Leren en Elektronische Leeromgevingen zou een te sterke focus op de ICT als oplossing voor scholingsvraagstukken vermeden moeten worden. Het gaat hier immers niet alleen om een ontwerpactiviteit, maar juist ook om de inbedding ervan in de organisatie en om het ontwikkelen van een passend didactisch concept. Ook dit vereist een interdisciplinaire benadering, waarbij scholingsvraagstukken vanuit een bredere optiek worden geanalyseerd. Daarbij dient aandacht geschonken te worden aan organisatievraagstukken en kennismanagement.

Voor de afstudeerrichting Leren en Elektronische Leeromgevingen is het van belang om op het snijvlak van onderwijspsychologie (met de nadruk op cognitieve en instructiepsychologie), kennistechnologie en informatietechnologie te komen tot een nieuwe interdisciplinaire benadering. De opleiding in Maastricht zou zich op dit punt met name sterk kunnen profileren door een verbinding te leggen met onderwijspsychologie en kennistechnologie. 


\section{Inleiding}

\subsection{Achtergrond}

De Universiteit Maastricht (UM) heeft in 1998 een commissie benoemd die een nieuwe opleiding Onderwijswetenschappen in Maastricht moet voorbereiden. De commissie heeft hierover in het voorjaar 1999 een conceptplan gepubliceerd. Beoogd wordt dat in oktober 1999 een advies aanvraag kan worden ingediend bij de Adviescommissie Onderwijs (ACO). In de adviesaanvraag dient ook een nadere onderbouwing te worden gegeven van de arbeidsmarktrelevantie van de nieuwe opleiding. De UM heeft het Researchcentrum voor Onderwijs en Arbeidsmarkt (ROA) verzocht om vanuit haar expertise een bijdrage hieraan te leveren. In dit kader heeft het ROA in de afgelopen maanden een verkennende studie uitgevoerd. De voorliggende notitie vormt hiervan het verslag.

\subsection{Profiel van de studie Onderwijswetenschappen}

De nieuwe studie onderwijswetenschappen beoogt een aparte bijdrage te leveren aan het palet van studies onderwijskunde in Nederland. Het eigen profiel van de studie komt tot uitdrukking door de volgende kenmerken:

C De eerste twee jaren van de opleiding zijn er op gericht studenten een brede basis te verschaffen, waarin de analyse van scholingsvraagstukken in cognitieve, onderwijskundige, organisatorische en maatschappelijke termen centraal staat. De studenten leren om ten behoeve van dit scholingsvraagstuk krachtige leeromgevingen te ontwerpen.

C Op basis van deze meer generieke basis kunnen vervolgens twee afstudeerrichtingen gekozen worden: Leren en Elektronische Leeromgevingen (LELo), waar vooral een ICT oplossing van scholingsvraagstukken centraal staat, en een afstudeerrichting Continu Leren voor en in de Professionele Praktijk (CLPP), waarin vooral het ontwerp van curricula voor de professionele praktijk centraal staat.

C De theoretische invalshoek van de opleiding wordt sterk bepaald door recente theorievorming over competentie-ontwikkeling, waarbij kennisontwikkeling binnen bepaalde vakgebieden een belangrijk thema is. De opleiding legt dan ook een sterk accent op de vraag op welke wijze de eisen vanuit het werkveld van de professional en in bredere zin vanuit het functioneren op de arbeidsmarkt en de te verwachte ontwikkelingen in de samenleving als geheel, op een adequate wijze vertaald kunnen worden in de curricula.

C De opleiding hanteert ook zelf het principe van een krachtige leeromgeving door gebruik van probleem-gestuurd en student-gecentreerd onderwijs, ondersteund met ICT.

\subsection{Opzet}

Om de arbeidsmarktrelevantie van een nieuwe opleiding te beoordelen is het noodzakelijk om na te gaan in hoeverre de nieuwe opleiding in een behoefte voldoet waarin het bestaande onderwijsaanbod nog onvoldoende voorziet. Deze behoefte kan zowel kwantitatief als kwalitatief van aard zijn. Enerzijds kan sprake zijn van een toekomstig tekort aan onderwijskundigen, bijvoorbeeld vanwege de ontwikkeling naar een kenniseconomie en de 
professionalisering van scholingsvraagstukken. Anderzijds kan sprake zijn van een kwalitatieve verschuiving van de vraag naar onderwijskundigen, bijvoorbeeld een behoefte aan onderwijskundigen die vanuit een andere, meer op vakspecifieke competenties gerichte invalshoek naar onderwijskundige problemen kijken of juist de ICT oplossingen voor scholingsvraagstukken kunnen aandragen. In de studie zijn beide aspecten betrokken, dus zowel de kwantitatieve vraag naar onderwijskundigen als de meer specifieke behoefte aan onderwijskundigen met het profiel LELo of CLPP. Voor de verkenning is gebruik gemaakt van desk-research en zijn gesprekken gevoerd met deskundigen uit het werkveld voor onderwijskundigen. In de bijlage is de lijst met gesprekspartners weergegeven.

De verkennende studie belicht een aantal ontwikkelingen in het initieel en niet-initieel onderwijs die naar verwachting consequenties zullen hebben voor de vraag naar onderwijskundigen. In het initieel onderwijs betreft dit met name:

$C$ de beleidsontwikkelingen in het primair onderwijs;

$\mathrm{C}$ de invoering van het studiehuis en het Voorbereidend Middelbaar Beroepsonderwijs (VMBO) in het voortgezet onderwijs;

$C$ de invoering van vormen van duaal leren in het hoger onderwijs;

C de ontwikkeling van de kwalificatiestructuur in het secundair beroepsonderwijs;

$C$ de invoering van ICT in het onderwijs;

C de professionele ontwikkeling van de beroepsgroep van leerkrachten.

Bij het niet-initiële onderwijs wordt een verkenning gemaakt van zowel de ontwikkelingen binnen de traditionele markten voor scholing als de ontwikkeling naar nieuwe institutionele vormen waarbinnen scholingsvraagstukken worden aangepakt. Binnen de traditionele markt kan een onderscheid worden gemaakt tussen de open markt (bijvoorbeeld open universiteit, LOI) en de consultancy en trainingsmarkt. Beide hebben te maken met een sterke groei van de vraag naar scholing, de ontwikkeling naar levenslang leren, afstandsleren etc. Naast deze meer traditionele markten voor training doen zich nieuwe vormen voor zoals de ontwikkeling naar kennis-onderhoudscontracten en de ontwikkeling naar bedrijfsacademies.

Vervolgens wordt een meer algemeen beeld geschetst van de arbeidsmarkt voor onderwijskundigen. In de bestaande onderzoeken en statistieken is nog onvoldoende materiaal beschikbaar over de ontwikkelingen in vraag en aanbod voor onderwijskundigen. Zo ontbreken vooralsnog voldoende gedetailleerde gegevens over de positie van pas afgestudeerde onderwijskundigen. Evenzo zijn de prognoses die het ROA tweejaarlijks opstelt alleen beschikbaar voor het geaggregeerde niveau van 'sociale wetenschappen' of 'pedagogische beroepen'. Wel zijn schattingen gemaakt van de in- en uitstroom in de studie onderwijskunde. De betreffende gegevens geven een beeld van de bredere arbeidsmarkt waarbinnen de toekomstige onderwijskundigen komen te functioneren. 


\subsection{Leeswijzer}

De opbouw van deze verkennende studie is als volgt. Hoofdstuk 2 belicht de belangrijkste ontwikkelingen in het initiële onderwijs. Hoofdstuk 3 gaat in op een aantal ontwikkelingen in het niet-initieel onderwijs. Tevens worden enkele cases besproken die een impressie geven van een aantal relevante ontwikkelingen. In hoofdstuk 4 wordt een schets gegeven van de arbeidsmarkt voor onderwijskundigen. In hoofdstuk 5 ten slotte worden de belangrijkste bevindingen belicht en enkele conclusies getrokken ten aanzien van het perspectief van een nieuwe opleiding Onderwijswetenschappen.

\section{Ontwikkelingen in het initieel onderwijs}

\subsection{Primair onderwijs}

Belangrijke beleidsontwikkelingen binnen het primair onderwijs betreffen de vergroting van de opvangmogelijkheden voor kinderen met leermoeilijkheden in het reguliere basisonderwijs in het kader van Weer Samen Naar School (WSNS), de bestrijding van onderwijsachterstanden voor leerlingen uit specifieke achterstandsgroepen in het kader van het Gemeentelijk Onderwijs Achterstandenbeleid (GOA) en de verschuiving van bepaalde bestuurlijke bevoegdheden van de rijksoverheid naar gemeenten en lokale schoolbesturen.

Als gevolg hiervan wordt netwerkvorming in het primair onderwijs steeds belangrijker. Belangrijke netwerken zijn:

C de samenwerkingsverbanden die op gemeentelijk niveau tussen basisscholen en speciale basisscholen ontstaan in het kader van WSNS;

C de netwerken die voortvloeien uit GOA;

$C$ netwerken die ontstaan als gevolg van de bestuurlijke schaalvergroting waardoor meerdere scholen onder één bestuur vallen;

C netwerken tussen lerarenopleidingen en scholen (zowel via de stages als de duale opleiding voor leraren).

Een belangrijk gevolg van deze netwerken is dat de professionele autonomie van leerkrachten verdwijnt en leerkrachten hun van oudsher geïsoleerde positie moeten opgeven. $\mathrm{Er}$ ontstaan binnen scholen en over scholen heen meer gespecialiseerde functies (bijvoorbeeld remedial teacher, bovenschools management, coördinatoren voor achterstandsbeleid). Door de schaalvergroting verschuift een deel van de werkgelegenheid van schoolbegeleidingsdiensten naar de scholen zelf, bijvoorbeeld op het gebied van remedial teaching. Daarnaast ontstaat meer bovenschools beleid en is met name op gemeentelijk niveau sprake van een uitbreiding en professionalisering van beleidsfuncties.

De betreffende ontwikkelingen hebben vanzelfsprekend ook gevolgen voor de vraag naar onderwijskundigen. Naar verwachting zal deze zich overigens vooral richten op degenen die in het onderwijs werkzaam zijn of zijn geweest. Bij de afgestudeerde onderwijskundigen 
betreft dit met name de afgestudeerden van de deeltijdopleidingen. Indirect heeft dit uiteraard wel een effect op de andere pas afgestudeerden.

De betreffende functies doen vooral een beroep op competenties als onderwijsbegeleiding en onderwijsmanagement en minder op ontwerpvaardigheden of ICT.

\subsection{Voortgezet onderwijs}

De invoering van het studiehuis en de doorstroomprofielen in het HAVO en VWO en het ineenschuiven van MAVO en VBO in het VMBO (Voorbereidend Middelbaar Beroepsonderwijs) kunnen beschouwd worden als de grootste verandering in de organisatie van het voortgezet onderwijs sedert de invoering van de Mammoetwet. Aanleiding voor deze veranderingen waren:

C knelpunten in de aansluiting tussen VBO/MAVO en het secundair beroepsonderwijs;

C knelpunten in de aansluiting tussen HAVO/VWO en het hoger onderwijs;

$C$ de grote voortijdige uitval alsmede het grote aantal leerlingen dat zonder startkwalificatie de arbeidsmarkt betreedt;

C ongelijke participatie in het onderwijs door de verschillende maatschappelijke groepen;

C veranderende eisen die gesteld worden aan de leerlingen;

$C$ veranderde opvattingen over het didactisch concept.

Het studiehuis beoogt de leerlingen een meer actieve rol te geven in het onderwijsproces. Daartoe wordt een deel van de verantwoordelijkheid voor de sturing van het onderwijsproces overgedragen van de leraar naar de leerling. De leraar zal het onderwijsproces daarbij meer op afstand gaan sturen. De rol van de leerkracht verandert van leider naar begeleider van onderwijsprocessen. Men zal de leerlingen meer moeten gaan aanspreken op hun competenties. Om het actief en zelfstandig leren te bevorderen worden andere werkvormen geïntroduceerd, waarbij momenten van instructie worden afgewisseld met perioden waarin de leerlingen zelfstandig of in groepjes aan opdrachten werken. De invoering van het studiehuis zal ook gevolgen hebben voor de wijze van toetsen. Leerlingen zullen individueel, op de momenten waarop ze er zelf aan toe zijn, feedback moeten krijgen over hun voortgang. Een belangrijk hulpmiddel daarbij is het gebruik van ICT. Dat betekent ook dat er goede educatieve software ontwikkeld moet worden.

De invoering van doorstroomprofielen beoogt vooral de aansluiting tussen het voortgezet en hoger onderwijs te verbeteren. In plaats van een vrije vakkenpakketkeuze moeten alle leerlingen een verplicht basisdeel volgen, dat ongeveer de helft van het totale studieprogramma omvat. Vervolgens kunnen de leerlingen kiezen uit vier profielen: Natuur en Techniek, Natuur en Gezondheid, Economie en Maatschappij en Cultuur en Maatschappij. Het profielgedeelte omvat ongeveer $30 \%$ van het studieprogramma. Ten slotte kan de leerling een deel van de vakken vrij kiezen. De invoering van de doorstroomprofielen gaat gepaard met een uitbreiding van het aantal vakken waarin de leerlingen les krijgen. 
MAVO en VBO gaan op in het VMBO. In de eerste jaren van het VMBO volgen de leerlingen basisvorming. Daarna volgt een keuze voor een leerweg en een sector. Een leerling kan kiezen uit een theoretische leerweg, een gemengde leerweg en een tweetal beroepsgerichte leerwegen die verschillen in niveau. Daarnaast kan een leerling kiezen voor één van de vier sectoren (zorg en welzijn, techniek, economie, landbouw) of voor één van de zogeheten intrasectorale programma's. Voor leerlingen die extra hulp nodig hebben is er leerwegondersteunend onderwijs. Hiermee bieden docenten de leerlingen de extra hulp die nodig is om het examen te halen. Leerlingen voor wie een leerweg, ondanks dit leerwegondersteunend onderwijs, te hoog gegrepen is kunnen naar het praktijkonderwijs dat rechtstreeks voorbereidt voor de arbeidsmarkt. Op dit moment worden in pilot projecten verschillende aspecten van leerwegondersteunend onderwijs en praktijkonderwijs beproefd. Deze pilot projecten worden uitgevoerd in samenwerkingsverbanden tussen scholen voor VSO (Voortgezet Speciaal Onderwijs), VBO en MAVO. De bedoeling is dat er in de toekomst geen aparte scholen voor voortgezet speciaal onderwijs meer bestaan.

De geschetste ontwikkelingen hebben belangrijke gevolgen voor de rol van docenten. In het VMBO zal vooral een beroep worden gedaan op de zorgdeskundigheid. In het HAVO en VWO zullen leerkrachten vooral vanuit een ander didactisch concept moeten leren denken. Er is daarom behoefte aan onderwijskundigen die deze ontwikkelingen kunnen ondersteunen, niet alleen bij de verzorgingsinstellingen, maar ook bij de lerarenopleidingen en de educatieve uitgeverijen. Er is grote behoefte aan nieuw leermateriaal, waarbij uit wordt gegaan van de nieuwe didactische concepten. Daarnaast is het belangrijk om toetsen te ontwerpen waarmee de ontwikkelingen van leerlingen meer continu gevolgd kunnen worden. Door één van de gesprekspartners werd aangegeven dat er in dit verband enkele belangrijke eisen aan onderwijskundigen dienen te worden gesteld:

$C$ het beschikken over ontwerpvaardigheden;

$C$ het goed kunnen analyseren van leersituaties;

$C$ inzicht in de manier waarop organisaties werken;

C goede communicatieve vaardigheden;

C interesse in mensen en leerprocessen.

\subsection{BVE}

De Wet educatie en beroepsonderwijs (WEB) vormt het voorlopig sluitstuk van de organisatorische vernieuwing in het secundair beroepsonderwijs. Doel van de wet is om meer samenhang te brengen in de beroepsopleidingen in het secundair onderwijs. Dit gebeurt enerzijds door de vorming van Regionale Opleidingscentra (ROC's) en Agrarische Opleidingscentra (AOC's) en anderzijds door het onderbrengen van alle beroepsopleidingen in één landelijke kwalificatiestructuur. De sector Beroepsgerichte en Volwasseneneducatie (BVE) omvat daarmee het initieel secundair beroepsonderwijs (zowel het voormalige (K)MBO als leerlingwezen), de volwasseneneducatie, maar ook een deel van de Continuing Vocational Training voor werkenden (in de vorm van contractonderwijs). 
Binnen de BVE speelt een aantal belangrijke beleidsontwikkelingen:

$C$ de invoering van de kwalificatiestructuur;

$C$ de verbetering van de aansluiting tussen BVE en $\mathrm{HBO}$;

$C$ de verbetering van de aansluiting tussen VMBO en BVE;

$\mathrm{C}$ internationale erkenning van vakdiploma's.

De invoering van de landelijke kwalificatiestructuur kan gezien worden als de derde fase in de ontwikkeling van eindtermen voor het beroepsonderwijs. Doelstellingen van de kwalificatiestructuur zijn:

C vergroting van de transparantie van opleidingen;

C opleiden voor nationaal en internationaal erkende beroepskwalificaties;

$C$ verbetering van de doorstroming tussen leerwegen;

C erkenning van elders verworven kwalificaties;

$C$ vermindering van de tussentijdse uitstroom.

Bij de ontwikkeling van de eindtermen is een belangrijke rol toebedacht aan de Landelijke Organen Beroepsonderwijs (LOB's) die op basis van beroepsprofielen eindtermendocumenten opstellen waarin per opleiding de vereiste kwalificaties worden weergegeven. Deze eindtermen dienen te voldoen aan bepaalde landelijke richtlijnen, het zogenaamde landelijke format, waarin eisen zijn geformuleerd ten aanzien van de duur, praktijkvorming en de breedte van de kwalificaties. Op basis van de eindtermendocumenten worden door de onderwijsinstellingen leerplannen opgesteld. De eindtermendocumenten dienen regelmatig herijkt te worden als gevolg van ontwikkelingen in het vakgebied.

De leerplanontwikkeling in het BVE-veld is tot nu toe sterk gestuurd geweest vanuit de vraagzijde. Zeker bij de eerste en tweede generatie eindtermen, maar ook bij de ontwikkeling van de derde generatie eindtermen is voornamelijk gekeken wat de arbeidsmarkt of mensen uit het werkveld vragen. Op basis hiervan zijn beroepsprofielen ontwikkeld. Door een aantal gesprekspartners is aangegeven dat het bij de ontwikkeling van eindtermen ontbroken heeft aan een duidelijk leerpsychologisch model waardoor een antwoord wordt gekregen op de vraag: wat zou het geschikte aanbod moeten zijn voor deze vraag vanuit het werkveld? De formulering van eindtermen moet meer zijn dan een verzameling vereisten waar een werknemer aan moet voldoen. De basis moet worden gevormd door een model dat aangeeft op welk wijze een leerling een ontwikkeling tot professional kan doormaken.

De Sociaal Economische Raad heeft in dit verband in een advies aan de minister over de invoering van de WEB aangegeven het wenselijk te vinden dat in de eindtermen meer aandacht wordt geschonken aan zogeheten sleutelkwalificaties ${ }^{1}$. Deze worden gedefinieerd als de kennis, inzicht, vaardigheden en houdingen die tot de duurzame kern van een beroep behoren. In vergelijking met specifieke handelingsvaardigheden kenmerken sleutelkwalificaties zich doordat ze een samenhangend geheel vormen, veelal in de context van een beroep geleerd worden en een hoge transferwaarde hebben. Met dit laatste wordt bedoeld

1. SER, Versterking secundair beroepsonderwijs, Den Haag, 1997. 
dat de betreffende kennis en vaardigheden ook in andere contexten kunnen worden toegepast, waardoor overgangen binnen de beroepsloopbaan vergemakkelijkt worden.

Een ander belangrijk issue in het BVE-veld betreft het kwalificeren van laag-opgeleide jongeren. In wezen gaat het hier om de vraag hoe in het onderwijs rekening kan worden gehouden met een heterogene instroom. Het streven is daarbij om leerlingen een minimale startkwalificatie te geven voor de arbeidsmarkt. Nauw verwant hiermee is de problematiek van de voortijdige uitval in het BVE. Op dit moment bedraagt die uitval zo'n 40-50\%. De landelijke kwalificatiestructuur beoogt onder meer de uitval in het BVE te verminderen en te komen tot meer efficiënte leerwegen. Ook de verbetering van de aansluiting met de vooropleidingen (VMBO) en het vervolgonderwijs (HBO) moeten in dit licht begrepen worden.

Het aanbieden van alternatieve leerroutes en het gebruik van leerlingvolgsystemen kunnen belangrijke hulpmiddelen zijn om de uitval te verminderen. Daarnaast moet meer aandacht geschonken worden aan de leermiddelen. Het leermateriaal in de BVE sector is volgens één van de gesprekspartners in de regel veel slechter dan in het algemeen voortgezet onderwijs (AVO). Dat komt voornamelijk door de grote versnippering in het aantal opleidingen en de snelheid van wijzigingen in de beroepspraktijk. Deze versnippering betekent dat in vergelijking met het AVO dit deel van de leermiddelenmarkt voor commerciële uitgeverijen veel minder interessant is. Daarom wordt een groot deel van het lesmateriaal in het grijze circuit gemaakt.

Geconcludeerd kan worden dat bij de verdere ontwikkeling van de kwalificatiestructuur, onderwijskundige ondersteuning bij het ontwerp van eindtermen en leerplannen onontbeerlijk is. Van belang is dat men vanuit een competentiegerichte en leerpsychologische benadering leerplannen kan ontwerpen voor de beroepspraktijk.

\subsection{Hoger Onderwijs}

Een recente onderwijskundige vernieuwing in het Hoger Onderwijs is de ontwikkeling van duale leerroutes. Krijgt in het reguliere voltijd onderwijs de relatie tussen onderwijs en beroepspraktijk vooral vorm in de stage, sinds enkele jaren bestaat ook de mogelijkheid om leren en werken te combineren in één opleiding. Hierbij wordt een onderwijsarbeidsovereenkomst afgesloten tussen de student, de hogeschool of universiteit en de arbeidsorganisatie waar de student werkzaam is. Oogmerk is om de afstemming tussen theorie en praktijk te verbeteren en een 'natuurlijke' overgang naar de beroepspraktijk te realiseren. Naast enkele pilots in het WO, zijn duale leerroutes met name gerealiseerd in het HBO. Hierbij worden diverse varianten onderscheiden, zoals coöperatief HBO (Coöp), de MKBroute, de duale variant van HBO-verpleegkunde, de LIO-opleiding (leraar in opleiding) en het Gilde HBO.

De dualisering moet eigenlijk beschouwd worden als een uitingsvorm van een bredere ontwikkeling die aangeduid kan worden als de toenemende behoefte aan maatwerk c.q. flexibilisering. Het onderwijs zal meer op de individuele behoefte van studenten moeten 
worden toegesneden. Dat geldt voor de reguliere instroom van jongeren, bijvoorbeeld via het opzetten van aparte trajecten voor doorstroom mbo-hbo of aparte trajecten voor allochtonen. Het maatwerk geldt ook voor de in omvang toenemende vraag vanuit de categorie ouderen, bijvoorbeeld van MBO'ers die reeds een tijd werkzaam zijn en een hoger kwalificatieniveau nodig hebben. Om deze mensen een goede opleiding te bieden is het noodzakelijk dat de in het werk verworven kwalificaties goed worden vastgesteld. Een belangrijk probleem daarbij is hoe dit gemeten moet worden.

In een recent advies met betrekking tot het Hoger Onderwijs wordt door de SER een pleidooi gevoerd voor het vergroten van de flexibiliteit van het onderwijs om in te kunnen spelen op een meer heterogene studentenpopulatie ${ }^{2}$. Daarbij gaat het niet alleen om de 'institutionele flexibiliteit' - de responsiviteit van het onderwijsstelsel met betrekking tot maatschappelijke veranderingen - maar ook om flexibiliteit van het onderwijsproces. Dit laatste vereist het doorvoeren van instrumenten als:

C programmatische flexibiliteit, waaronder het ontwikkelen van mechanismen om een marktoriëntatie te realiseren;

C flexibiliteit in het curriculumontwerp: de opleidingen zullen steeds sneller innovaties in het vakgebied moeten verwerken in hun opleiding;

C didactische flexibiliteit, waaronder de mogelijkheid om onderwijs te doorlopen via verschillende trajecten die aansluiten bij verschillen in leerstijlen en een gedifferentieerd aanbod van leerlingen (bijvoorbeeld ouderen met praktijkervaring);

C organisatorische flexibiliteit, bijvoorbeeld door het creëren van meerdere instroommomenten in de opleiding.

De toenemende noodzaak tot flexibiliteit creëert vanzelfsprekend een spanningsveld tussen het leveren van maatwerk en de transparantie van het onderwijsaanbod. Om niet te vervallen in een 'cafetaria-systeem' moet de samenhang van het onderwijsaanbod worden gewaarborgd door het formuleren van een initieel 'kern-curriculum' en systematisch daaraan gerelateerde additionele opleidingen. In het HBO vindt de herijking van opleidingen plaats in landelijke werkveldcommissies waar het HBO en het werkveld in vertegenwoordigd zijn. Deze landelijke commissies stellen de opleidingsprofielen vast op basis van zogeheten kernkwalificaties. Deze kernkwalificaties beslaan ongeveer $70 \%$ van de opleiding. De rest is door een instelling geheel vrij in te vullen. Kernkwalificaties zijn beschreven in termen van competenties: wat moet iemand kunnen? Voor de ontwikkeling van opleidingsprofielen is geen landelijk format vastgelegd, zoals bij het BVE-veld. Bij het HBO wordt de invulling per opleiding weer anders geregeld. Hoewel de competenties centraal worden vastgesteld kunnen de eindtermen per instelling verschillen. Dat betekent dat er ook geen landelijk richtlijnen zijn over de toetsing van het eindniveau.

In onderwijskundig opzicht is er behoefte aan ondersteuning om de individuele leertrajecten en individueel assessment vorm te geven. In het verlengde hiervan ontstaan vraagstukken over de onderlinge relatie tussen de verschillende kwalificaties, bijvoorbeeld hoe sluiten de opleidingen onderling op elkaar aan? Daarnaast is behoefte aan een verdere ontwikkeling van

2. SER, Advies HOOP 2000, Den Haag, 1999. 
een stelsel van toetsing. Accreditering en certificering staan nu nog in de kinderschoenen en dienen verder ontwikkeld te worden. Van belang is wel dat de toetsen domeinspecifiek zijn. Dit vereist van de toetsontwikkelaars dat ze een grote betrokkenheid hebben met het werkveld.

Een andere belangrijke ontwikkeling in het hoger onderwijs betreft de extensivering van het onderwijs. Dit betekent dat de staf-student ratio kleiner wordt. Een belangrijk probleem is hoe men ondanks deze extensivering de kwaliteit van de opleiding kan handhaven. Extensivering vereist de introductie van andere werkvormen, waarbij zelfstandig studeren belangrijker wordt. Een belangrijk hulpmiddel hierbij is natuurlijk de ICT. De mogelijkheden van ICT bij met name het docent-onafhankelijke onderwijs is een belangrijk aandachtspunt bij het vormgeven van zowel de programmatische als de didactische flexibiliteit.

Geconcludeerd kan worden dat er behoefte is aan onderwijskundigen die ondersteuning kunnen geven bij het ontwikkelen van leerroutes die een directe combinatie van leren en werken omvatten alsmede de ontwikkeling van individuele leerroutes. Daarnaast is ondersteuning nodig bij de ontwikkeling van domeinspecifieke toetsen en een stelsel van accreditering en certificering. Ten slotte heeft men behoefte aan onderwijskundigen die de mogelijkheden van ICT ten behoeve van docent-onafhankelijk onderwijs weten toe te passen.

\subsection{ICT}

In de literatuur worden in de regel vier functies onderscheiden met betrekking tot onderwijs en $\mathrm{ICT}^{3}$ :

C leren over ICT (hoe werkt ICT en wat zijn de toepassingsmogelijkheden?);

C leren met behulp van ICT (het gebruik van ICT als hulpmiddel in het onderwijsleerproces; kenmerkend is de inhoudelijke onafhankelijkheid van het leermiddel);

C leren door middel van ICT (gebruik van ICT als leermiddel, waarbij ICT geïntegreerd is in het leerproces, bijvoorbeeld als tutorial);

C ICT ter ondersteuning van de schoolorganisatie en het kennismanagement.

Van den Dool et al. (1999) signaleren in de ICT-gemedieerde leerprocessen ook een verschuiving van het gebruik van de computer van individuele ondersteuning (Learning alone) naar samenwerkend leren (Learning together). Hierbij wordt een onderscheid gemaakt tussen: Computer Supported Collaborative Learning (CSCL) en Computer Supported Collaborative Working (CSCW). De grens tussen CSCL en CSCW zal overigens vervagen, waardoor de principes die bij het ene gebied zijn ontwikkeld ook steeds meer zullen worden toegepast bij het andere gebied.

3. Zie P. van den Dool, J. Moonen en A. Kraan, Van didactische driehoek naar lerend veelvlak, NWOPROO, Den Haag, 1999. 
De overheid is in 1997 een actieprogramma gestart om de invoering van ICT in het onderwijs te bevorderen ${ }^{4}$. De ondersteuning van de overheid heeft betrekking op een viertal terreinen:

$C$ de aansluiting van scholen op het onderwijs-intranet (Kennisnet) waardoor internetdiensten voor het onderwijs beschikbaar komen;

C deskundigheidsbevordering van docenten en schoolleiders onder meer door het scheppen van landelijke kaders voor de certificering van onderwijspersoneel ('digitaal rijbewijs');

C stimulering van goede educatieve software;

C monitoring en evaluatie van de invoering van ICT in het onderwijs.

In de onlangs uitgebrachte nota Onderwijs on-line van het Ministerie van OC\&W zijn deze uitgangspunten nog eens bevestigd en is aan de onderwijsinspectie een specifieke taak toebedacht om toezicht te houden op de invoering. Dat betekent dat in de komende periode veel behoefte bestaat aan specifieke expertise om het daadwerkelijke gebruik van ICT in het onderwijs verder te stimuleren.

De Onderwijsraad heeft in een onlangs uitgebracht advies ${ }^{5}$ over het ICT-beleid benadrukt dat ICT bij uitstek kansen biedt het didactisch proces te vernieuwen. De Raad constateert een ontwikkeling van 'teaching' naar 'learning', waarbij de docent meer begeleider wordt van het leerproces. Deze veranderende rol van docenten impliceert een actievere participatie van leerlingen in het onderwijsproces. De Raad stelt voor om de ontwikkeling van ICTtoepassingen te stimuleren die gericht zijn op dit nieuwe didactische concept, zoals WEBtoepassingen en 'groupware'.

Ook Van den Dool et al. (1999) waarschuwen in hun voorstel voor een onderzoeksprogramma op het terrein van onderwijstechnologie ${ }^{6}$, voor een fixatie op de introductie van hardware en netwerken. Zij pleiten voor meer aandacht voor het daadwerkelijk integreren van ICT in de reguliere en innovatieve onderwijspraktijk. Van belang daarbij is goede kennis over de educatieve instrumentatie op basis van ICT en over door ICT gemedieerde leerprocessen. In het verlengde hiervan pleiten zij voor onderzoek naar het modelleren van de nieuwe leeromgeving en het ontwikkelen van een passende didactiek. Door één van de gesprekspartners werd opgemerkt dat hier ook mogelijkheden liggen voor softwareontwikkelaars om ondersteuning te bieden. Programma's kunnen zo ontworpen worden dat leerlingen stapsgewijs leren. Hiermee verkrijgen leerkrachten en leerlingen zowel diagnostisch inzicht (wat heeft iemand geleerd), als inzicht in de wijze waarop leerlingen leren.

Om de benutting van ICT in het onderwijs en op het werk te bevorderen, is er steeds meer behoefte aan experts die een sterk ontwerpgerichte oriëntatie hebben. Ontwerp moet daarbij breed worden opgevat. Het gaat niet alleen om het meer 'technische' ontwerp zelf, maar ook

4. Ministerie van Onderwijs, Cultuur en Wetenschappen, Investeren in voorsprong, Actieplan voor Informatie en Communicatietechnologie, Zoetermeer, 1997.

5. Onderwijsraad, Leren met ICT: nieuwe accenten, Den Haag, 1999.

6. P. van den Dool, c.s., op.cit. 
om de inbedding ervan in een onderwijsleersituatie. Er is behoefte aan mensen die ICT toepassingen kunnen inbedden in een organisatie. In de interviews kwam naar voren dat op scholen wel veel geïnvesteerd is in apparatuur, maar dat de daadwerkelijke implementatie van ICT nog achterwege blijft ${ }^{7}$.

Een belangrijke ontwikkeling is dat door ICT het fenomeen leermiddel in het totale onderwijsontwerp steeds belangrijker wordt. De variëteit in leermiddelen zal steeds groter worden en daarmee ook de vraag naar de kwaliteit van de verschillende leermiddelen. Vanuit Kennisnet geïnitieerd worden databanken op dit gebied opgezet. ICT kan een rol gaan spelen in de disseminatie en hergebruik van leermiddelen. Het is overigens de vraag hoe snel en uitgebreid dit zal gaan. De Open Universiteit heeft in het verleden ook een belangrijke rol gespeeld bij de ontwikkeling van lesmaterialen en toch blijkt dat bij universiteiten de disseminatie van innovatief lesmateriaal langzaam gaat. Wel werkt ICT faciliterend op de ontwikkeling van leermiddelen.

ICT zal daarnaast een steeds belangrijker rol gaan spelen ter ondersteuning van de schoolorganisatie alsmede op het terrein van kennismanagement. Kennismanagement beperkt zich uiteraard niet tot het onderwijs, maar strekt zich uit tot alle organisaties die met informatie te maken hebben. Daarbij gaat het om alles wat te maken heeft met het geheugen van de organisatie. Belangrijke vragen in dit verband zijn: Hoe kun je de kennis die in een organisatie aanwezig is toegankelijk maken voor alle medewerkers (of de klanten)? Hoe kun je mensen leren om met dat soort kennissystemen om te gaan? Wat voor competenties heb je daarvoor nodig? De inzichten op het gebied van kennismanagement kunnen ook in de onderwijssector geïmplementeerd worden. Zo is door enkele gesprekspartners aangegeven dat het belangrijk is dat leerkrachten in het onderwijs zicht krijgen op de kennisinfrastructuur, de ontwikkeling van expertsystemen en databases. Het kennisnetwerk kan in die zin ook gebruikt worden in de context van de professionele ontwikkeling van de beroepsgroep van leerkrachten.

Geconcludeerd kan worden dat er behoefte is aan onderwijskundigen die in staat zijn om ICT toe te passen in nieuwe didactische concepten. Van belang daarbij is dat men niet alleen over ontwerpvaardigheden beschikt, maar in staat is om een ontwerp in te bedden in een onderwijsleersituatie. Daarnaast is aandacht vereist voor vraagstukken rond kennismanagement.

7. Dat geldt overigens ook voor veel bedrijven. De organisatie SENTER heeft bijvoorbeeld een stimuleringsprogramma ontwikkeld om leren in de werkomgeving te bevorderen. 


\subsection{Ontwikkelingen in de beroepsgroep van leerkrachten}

Het beroep van leerkracht is lange tijd gekenmerkt geweest door een hoge mate van professionele autonomie en sterke regulering van de markt door de overheid. Door een aantal ontwikkelingen is dit in snel tempo aan het veranderen:

C veranderingen in de rol van de docent;

C veranderingen in de regelgeving van de overheid;

C ontwikkeling van de beroepsgroep van leerkrachten als professie.

Veranderende rol van de docent

Als gesproken wordt over de professionele autonomie van leerkrachten, dan is deze natuurlijk altijd begrensd geweest. De leerkrachten in het primair onderwijs kennen een lange traditie van werken in teamverband, terwijl in het voortgezet onderwijs (VO) een sterke gerichtheid bestond op de vaksectie. Leraren in het VO identificeren zich daarom volgen één van de gesprekspartners in de eerste plaats met hun vak, en pas vervolgens met het beroep van leraar. De professionalisering heeft daarom lange tijd vooral betrekking gehad op de vakdidactiek.

Eerder is gesignaleerd dat als gevolg van netwerkvorming in het primair onderwijs de professionele autonomie van leerkrachten wordt doorbroken. Er ontstaan netwerken tussen basisscholen onderling, tussen basisscholen en scholen voor speciaal onderwijs en tussen basisscholen en de lerarenopleidingen. Binnen en tussen scholen ontstaan hierdoor gespecialiseerde functies, met zowel taakverbreding als taakdifferentiatie.

In het voortgezet onderwijs zal vooral de invoering van het studiehuis en de invoering van ICT de rol van docenten aanzienlijk veranderen. De leraar wordt daarbij meer een begeleider van leerprocessen. Ook zal men met leerkrachten uit ander vaksecties gezamenlijk leerplannen moeten gaan ontwikkelen. Dit betekent dat een groter accent zal komen te liggen op de algemene didactische vaardigheden van docenten. Bovendien zal een nieuw leerconcept moeten worden ontwikkeld. De huidige leerconcepten zijn sterk gericht op de kennis die een leerling moet beheersen. In plaats daarvan zal meer aandacht nodig zijn voor de competenties die een leerling moet verwerven.

\section{Veranderingen in de regelgeving}

De rol van de overheid op het terrein van het personeelsbeleid in het onderwijs is vooral volgend en gericht op het wegnemen van belemmeringen. Het beleid van de overheid heeft betrekking op drie hoofdterreinen ${ }^{8}$ :

C vergroting van de instroom van leraren;

C bewaking van de kwaliteit van het personeel;

C de regulering op het gebied van arbeidsvoorwaarden en organisatie van het werk.

8. Ministerie van Onderwijs, Cultuur en Wetenschappen, Maatwerk voor morgen, Zoetermeer, 1999. 
De vergroting van de instroom van personeel moet gezien worden tegen de achtergrond van de nijpende personeelstekorten. Het beleid is zowel gericht op het vergroten van de reguliere instroom in de lerarenopleidingen als het vergroten van de zogenaamde zij-instroom. Hiermee wordt bedoeld dat vanuit belendende beroepen men de mogelijkheid moet krijgen om in een maximaal 2-jarige opleiding een bevoegdheid te krijgen. Op grond van een assessment moet een individueel opleidingsplan voor deze zij-instromers worden opgesteld. De niet-bevoegde leraren krijgen een tijdelijke aanstelling totdat men voldoet aan de vereisten voor startbekwaamheid. Bij het assessment ligt de nadruk op de vraag over welke competenties men beschikt en hoe men dan verder geschoold moet worden.

Wat betreft het toezicht op de kwaliteit wordt in de nota 'Maatwerk voor morgen' voorgesteld om te komen tot een Register voor leraren analoog aan het model dat voor de gezondheidszorg geldt op basis van de Wet BIG. In de nota wordt geconstateerd dat het huidige stelsel te weinig prikkels bevat om tegemoet te komen aan de nieuwe kwaliteitseisen die de veranderende tijd en de onderwijsvernieuwingen vragen. Bovendien dient bij een verruiming van de toegang tot het beroep, ook de kwaliteit van het beroep gewaarborgd te blijven. Tegelijk met de invoering van het Register worden daarom nieuwe startbekwaamheidseisen vastgesteld waarin de competenties voor leraren voor de komende periode worden beschreven. Door periodieke herregistratie worden leerkrachten gestimuleerd om hun vakbekwaamheid te onderhouden. Hierbij dient een systeem van certificering of accreditering ontwikkeld te worden, waardoor leraren kunnen aantonen, bijvoorbeeld door het gevolgd hebben van nascholing of andere vormen van deskundigheidsbevordering, dat men aan de nieuwe bekwaamheidseisen voldoet. De eerste set bekwaamheidseisen is onder leiding van de landelijke pedagogische centra ontwikkeld. De verantwoordelijkheid voor de kwaliteit van het leraarschap komt bij de beroepsgroep zelf te liggen, in casu bij de Stichting Samenwerkingsorgaan Beroepskwaliteit Leraren.

De voorstellen in het kader van de registratie sluiten ook nauw aan bij de voorstellen rond arbeidsvoorwaarden en integraal personeelsbeleid. Door functie- en taakdifferentiatie beoogt men het leraarsberoep aantrekkelijker te maken. Differentiatie kan een rol spelen bij het verminderen van de werkdruk, de vermindering van het lerarentekort en de vergroting van de carrière- en loopbaanmogelijkheden. Door taakdifferentiatie kunnen bijvoorbeeld nieuwe functies worden gecreëerd zoals klasse-assistenten of technisch-administratief personeel, die het primaire onderwijsproces moeten ondersteunen. Daarnaast wordt gepleit voor minder uniformering en meer differentiatie in het aanbod van arbeidsvoorwaarden, bijvoorbeeld door arbeidsmarkttoeslagen of de invoering van competentiebeloning.

\section{Professionalisering van de beroepsgroep van leerkrachten}

De ontwikkeling van de professie is bij het onderwijs pas laat op gang gekomen in vergelijking met bijvoorbeeld de gezondheidszorg, alhoewel ook daar pas bij de invoering van de BIG een grote rol werd toegekend aan de individuele kwaliteiten van de beroepsbeoefenaren. Kenmerkend is dat het onderwijs zich pas in een laat stadium is gaan buigen over 
beroepsprofielen. Een jaar of zeven geleden zijn beroepsprofielen verschenen voor de leerkrachten primair en voortgezet onderwijs, onlangs is een beroepsprofiel verschenen voor de schoolbegeleider.

De ontwikkeling van beroepsprofielen en het denken in termen van eindtermen kan volgens één van de gesprekpartners beschouwd worden als de eerste fase van professionalisering van het beroep van leerkracht. De aandacht ging daarbij vooral uit naar het ontwerpen en het bouwen van curricula. De tweede fase van deze ontwikkeling zou gericht moeten zijn op de processen van verwerving van competenties. $\mathrm{Er}$ is behoefte aan een leerpsychologisch model van de wijze waarop professionals hun competenties verwerven. Zowel in het beleid als in de school zelf komt meer en meer aandacht voor competentiemanagement en de wijze waarop vanuit de ervaring in de praktijk competenties verworven worden.

Een belangrijk aspect van de professionalisering van het beroep van leraar is dat men zich voortdurend moet bijscholen, verdiepen en reflecteren op het vak. Bovendien moet de hedendaagse professional - in plaats van de professionele autonomie van vroeger voortdurend in collegiaal gesprek zijn met andere beroepsgroepsbeoefenaren. In andere sectoren, zoals maatschappelijk werk of gezondheidszorg was supervisie of collegiaal consult al veel langer gemeengoed. In het onderwijs is dat pas laat tot ontwikkeling gekomen. Door de gesprekspartners is aangegeven dat ICT ook een belangrijke rol kan spelen bij de verdere ontwikkeling van de beroepsgroep. Hierbij zou het dan met name gaan om het communicatie-aspect van ICT. Door ICT kan de professionele netwerkvorming versterkt worden.

Geconcludeerd kan worden dat de beroepsgroep van leerkrachten een belangrijke doelgroep vormt voor een studie onderwijskunde, zowel wat betreft de instroom van potentiële studenten als wat betreft het object van studie in de opleiding. Door de professionaliseringstendensen zal meer behoefte bestaan om zich via het volgen van aanvullende opleidingen verder te kwalificeren. Dit kan leiden tot een vergroting van de instroom van met name deeltijdstudenten. Daarnaast kan de beroepsgroep van leerkrachten ook object van studie in de opleiding zelf zijn. Een centrale vraag is immers op welke wijze de competentie ontwikkeling van leerkrachten zelf plaats vindt. Dit onderwerp lijkt met name goed aan te sluiten bij de afstudeerrichting CLPP.

\section{Ontwikkelingen in het niet-initiële onderwijs}

\subsection{Oorzaken van de toenemende betekenis van het niet-initieel onderwijs}

De laatste jaren is er zowel bij het bedrijfsleven, het onderwijs en de overheid een toenemende aandacht voor het belang van het niet-initiële onderwijs. Hieraan ligt grosso modo een tweetal maatschappelijke ontwikkelingen ten grondslag:

C een upgrading van de op de arbeidsmarkt vereiste kwalificaties en een toenemende vraag naar communicatieve en ICT competenties; 
C een toenemende noodzaak kwalificatie-veroudering te voorkomen en de employability van werknemers te vergroten.

\section{Upgrading}

In de eerste plaats is er in vrijwel alle sectoren van de economie sprake van een upgrading van de kwalificatie-eisen. De globalisering van de afzetmarkt en de snelle technologische ontwikkeling leiden ertoe dat steeds hogere eisen worden gesteld aan de vereiste competenties $^{9}$. Deze ontwikkeling doet zich zowel voor bij het uitvoerende werk, waarbij het vereiste kwalificatie-niveau de afgelopen jaren verschoven is van VBO- naar MBO-niveau ${ }^{10}$, als bij de hogere functies waar in verschillende sectoren (bijvoorbeeld management, P\&O, journalistiek) sprake is van een 'academisering' van het vereiste kwalificatieniveau.

Uit internationaal onderzoek blijkt dat met name de toenemende informatisering en de daaraan gerelateerde organisatorische veranderingen een belangrijke oorzaak vormen van de toenemende kwalificatie-eisen. De snelle technologische ontwikkelingen leiden tot een toenemende complexiteit van veel functies, terwijl men bovendien naast de vakspecifieke competenties ook over bepaalde ICT competenties dient te beschikken. Daarnaast bewerkstelligen de technologische ontwikkelingen vaak ook organisatorische veranderingen, zoals het schrappen van management-lagen ('plattere' organisaties), decentralisering, empowerment e.d., die op hun beurt de kwalificatie-eisen weer verder doen stijgen ${ }^{11}$.

Een belangrijke rol daarbij speelt ook dat massa-productie in alle sectoren plaats maakt voor op de consument afgestemd maatwerk en een toenemend belang van de kwaliteit van de geleverde goederen en diensten. Dit laatste komt ook tot uiting in de sterk toegenomen aandacht voor kwaliteitszorg. Zowel bij de meer op de proceskwaliteit gerichte kwaliteitszorg (ISO-normering) als bij de meer op inhoud c.q. product gerichte kwaliteitszorg (Total Quality Management) is er doorgaans expliciet oog voor het belang van adequaat geschoold personeel en frequente bijscholing. Hierbij gaat het zowel om het eigen personeel als om het personeel van de toeleveranciers. Deze kwaliteitszorg noodzaakt ook tot een certificering van de kwalificaties van het personeel, die men on-the-job of elders door ervaring heeft verworven. Door 'assessment' testen kan men voor de Elders Verworven Competenties (EVC's) een formele algemeen erkende kwalificatie krijgen ${ }^{12}$.

9. Zie bijvoorbeeld S. van Wijnbergen, Fiscaliteit en werkloosheid, in: Belastingherziening in het fin de siècle, Preadviezen van de Koninklijke Vereniging voor de Staathuishoudkunde, LEMMA, Utrecht, 1998, p. 59.

10. Zie A. de Grip en R. Dekker, Winnaars en verliezers op de arbeidsmarkt 1985-1990, Tijdschrift voor Arbeidsvraagstukken, Vol. 9, 1993, p. 220-229.

11. Zie E. Caroli, Technical Change, Work Organisation and Skills: Theoretical Background and Implications for Education and Training, in: Training for a Changing Society, CEDEFOP, Office for Official Publications of the European Communities, Luxembourg, 1998, p. 103-113.

12. Zie B. van Gent en H. van der Zee (Red.), Competentie en arbeidsmarkt, Elsevier, Den Haag, 1998. 
De toenemende aandacht voor de kwaliteit van de dienstverlening leidt daarnaast in veel vakgebieden tot een sterk toenemende vraag naar mensen met communicatieve vaardigheden, terwijl de informatisering leidt tot een groeiende behoefte aan mensen met ICT-kennis en vaardigheden ${ }^{13}$. Deze beide ontwikkelingen leiden tot een sterk toenemende vraag naar (bij)scholing op deze terreinen. Gezien de snelle ontwikkelingen op ICT-gebied ligt in veel functies de frequentie waarmee opleidingen en cursussen worden gevolgd erg hoog.

\section{Kwalificatieveroudering en employability}

Vanwege de toenemende 'vergrijzing' van de beroepsbevolking worden de maatschappelijke kosten van het op relatief jonge leeftijd terugtreden van de arbeidsmarkt steeds groter. Veel van de uittredingswegen voor oudere werknemers worden wegens financieringsproblemen afgesloten (VUT, WAO, e.d.). Bovendien maakt het teruglopende aantal jongeren (de 'ontgroening') het voor werkgevers belangrijker om werknemers langer aan de slag te houden, om de knelpunten in de personeelsvoorziening te verminderen ${ }^{14}$.

Het afremmen van de vroegtijdige arbeidsmarktuitstroom van oudere arbeidskrachten noodzaakt tot wat wel wordt aangeduid als een 'leeftijdsbewust personeelsbeleid'. Het voorkomen van kwalificatieveroudering door bij- en of omscholing speelt daarbij een cruciale rol $^{15}$. Hierbij kan een aantal soorten van kwalificatieveroudering worden onderscheiden ${ }^{16}$ :

C slijtage als gevolg van het natuurlijk ouderwordingsproces, letsel of ziekte;

C atrofie vanwege het onvoldoende gebruiken van eerder verworven kwalificaties;

C functie-inhoudelijke kwalificatie-veroudering vanwege veranderde kwalificatie-eisen voor de functie die men uitoefent;

C kwalificatieveroudering vanwege een krimpende werkgelegenheid in een bepaald beroep of bedrijfssector;

C bedrijfsspecifieke kwalificatieveroudering vanwege reorganisatie of bedrijfssluiting.

In economische terminologie kunnen de eerste twee vormen van kwalificatie-veroudering worden gezien als een 'technische veroudering' van menselijk kapitaal, terwijl de drie laatstgenoemde vormen van kwalificatieveroudering als een 'economische veroudering' van menselijk kapitaal kunnen worden aangeduid.

Vanwege de continue noodzaak kwalificatie-veroudering als gevolg van met name technologische en organisatorische vernieuwingen te voorkomen wordt het belang van 'levenslang

13. Zie bv. F. Green, D. Ashton, B. Burchell, B. Davies \& A. Felstead, Are British workers getting more skilled?, in: L. Borghans \& A. de Grip (Eds.), The Overeducated Worker? The Economics of Underutilization of Skills, Edward Elgar, Cheltenham, 2000, p. 77-106.

14. Zie bv. L. Borghans c.s. Toekomstverkenning arbeidsmarkt en scholing tot 2007, Ministerie van Sociale Zaken en Werkgelegenheid, Den Haag, 1998.

15. Zie bv. Ministerie van Onderwijs, Cultuur en Wetenschappen, Nationaal actieprogramma 'een leven lang leren', Sdu, Den Haag, 1998.

16. ROA, Werkgelegenheid en scholing 1997, ROA-R-1998/1, Maastricht, 1998. 
leren' steeds uitdrukkelijker gerelateerd aan de employability van werkenden: ket vermogen van mensen om werk te krijgen en te houden'17. Werknemers worden daarbij gezien als zelfredzame personen die de zekerheid van een baan inruilen voor de zekerheid van werk. Deze zekerheid wordt verkregen door er voortdurend voor te zorgen dat men over een voor de arbeidsmarkt aantrekkelijk kennis- en vaardighedenpakket beschikt ${ }^{18}$.

\subsection{Toename scholingsparticipatie}

In 1993 werd volgens het CBS in de particuliere sector reeds bijna 3,5 miljard gulden uitgegeven aan interne en externe opleidingen van werkenden. Jaarlijks volgt bijna een kwart van de werknemers één of meer cursussen. Tussen 1986 en 1993 bedroeg de groei van de scholingskosten maar liefst ruim $60 \%$. Met name bij de financiële instellingen, energie- en waterleidingsbedrijven, de chemische sector, garagebedrijven, de vervoer en communicatiesector en de metaalindustrie is de scholingsparticipatie van werkenden $\operatorname{groot}^{19}$. De scholingsparticipatie concentreert zich in sterke mate bij de werkenden met een initiële opleiding op MBO-, HBO- of universitair niveau. Degenen die niet over een 'startkwalificatie' op $\mathrm{MBO} /$ Leerlingwezen-niveau beschikken participeren daarentegen veel minder in nietinitiële opleidingen, met uitzondering van degenen met een MAVO-diploma. De scholingsparticipatie is verreweg het hoogst in de leeftijdsgroep van 25-34 jaar en neemt vooral sterk af bij de werknemers van 55 jaar en ouder ${ }^{20}$.

De niet-initiële scholingsinspanningen blijken opvallend vaak zeer substantieel te zijn. Zo blijkt dat jaarlijks maar liefst bijna 220.000 mensen door het volgen van een niet-initiële opleiding een substantieel andere opleidingsachtergrond te krijgen, in de zin van een verhoging van iemands opleidingsniveau of een verandering van opleidingsrichting. Meer dan de helft van deze niet-initiële opleidingen bevindt zich op MBO-niveau (130.000), terwijl bijna 50.000 mensen via een niet-initiële opleiding een HBO- of WO-niveau verwerft ${ }^{21}$. Ruim 60.000 van deze niet-initiële opleidingen zijn gevolgd door degenen die werkzaam zijn in een economisch-administratief beroep, 32.000 zijn werkzaam in een technisch beroep en 30.000 in een verzorgend of dienstverlenend beroep. Daarnaast sluiten jaarlijks ook ruim 10.000 mensen die werkzaam zijn in een pedagogisch beroep (met name leerkrachten) een richtingveranderende of niveau-verhogende niet-initiële opleiding $\mathrm{af}^{22}$.

17. Ministerie van OCenW, op. cit.

18. J. Thijssen, Employability en employment: terminologie, modelvorming en opleidingspraktijk, Opleiding \& Ontwikkeling, 1997, nr. 10, p. 9-14.

19. M. van Smoorenburg en A. de Grip, De scholingsinspanningen van bedrijven: trainen of werven, Economisch-Statistische Berichten, Vol. 82, 1997, p. 848-849.

20. A. Gelderblom c.s., Integratie van leren en werken, OSA-W 162, Den Haag, 1998.

21. De niet-initiële opleidingen op WO-niveau hebben ook betrekking op de post-academische (beroeps)opleidingen.

22. A. de Grip en A. Jacobs, De betekenis van additionele scholing, Economisch-Statistische Berichten, Vol. 84, 1999, p. 416-418. 
Uit een recentelijk door het ROA in opdracht van het Ministerie van Sociale Zaken en Werkgelegenheid ontwikkelde 'Sectorale Employability Index' komt naar voren dat de employability-behoefte vanwege technologische, organisatorische, economische en demografische ontwikkelingen het grootst is in de sectoren energie, chemie, metaal en elektrotechniek, overheid en onderwijs en de zakelijke dienstverlening. In de meeste van deze sectoren is de employability van de werkenden ook op een relatief hoog niveau. Opmerkelijke uitzondering daarbij is de sector overheid en onderwijs ${ }^{23}$. Juist in deze sector wordt de laatste jaren wel geprobeerd een leeftijdsbewust personeelsbeleid van de grond te krijgen.

\subsection{Verschuivingen in de markt voor niet-initieel onderwijs}

Vervaging van de grenzen van de traditionele marktsegmenten

De gesignaleerde toenemende aandacht voor levenslang leren en de toegenomen scholingsparticipatie is waarschijnlijk ook een belangrijke oorzaak voor de verschuivingen die zich momenteel voordoen op de markt voor niet-initieel onderwijs. Traditioneel was de 'markt' in een zestal segmenten opgedeeld:

C het afstandsonderwijs op de open markt;

C het contactonderwijs op de open markt;

C de trainingsmarkt;

C de publieke scholing vanuit de arbeidsvoorzieningsorganisatie e.d.;

C de sectorale scholingsvoorzieningen;

C de interne bedrijfsopleidingen.

De laatste jaren is er duidelijk sprake van vervaging van de grenzen tussen de verschillende marktsegmenten. Deze vervaging heeft zowel betrekking op de inhoud en de vorm van het aangeboden niet-initiële onderwijs, als op de aanbieders van het onderwijs. Opvallend daarbij is ook dat de door de overheid bekostigde onderwijsinstellingen zich steeds meer op de markt voor het niet-initieel onderwijs begeven. Met name de ROC's en de Hogescholen spelen vanuit een sterke marktoriëntatie een steeds grotere rol in het niet-initieel onderwijs. Door de opkomst van de duale onderwijstrajecten in het HBO vervaagt de scheidslijn tussen het initiële en het niet-initiële onderwijs.

23. A. de Grip, J. van Loo en J. Sanders, Employability in Nederland, Economisch-Statistische Berichten, Vol. 84, 1999, p. 116-118. 
De door de overheid bekostigde onderwijsinstellingen hebben in toenemende mate oog voor de aanvullende scholing waar hun abituriënten in hun arbeidsloopbaan behoefte hebben. Hoewel er reeds langere tijd door Hogescholen en universiteiten binnen veel vakgebieden cursussen in het kader van het post-hoger onderwijs worden aangeboden is er de laatste tijd duidelijk sprake van een verder gaande professionalisering van de vormgeving van dit posthoger onderwijs. Een belangrijke ontwikkeling op dit punt is het aanbieden van zogenaamde kennis-onderhoudscontracten.

\section{Case: Ichtus Hogeschool te Rotterdam}

Een voorloper op het gebied van kennis-onderhoudscontracten is de Ichtus Hogeschool. Deze Hogeschool maakt een onderscheid tussen zogenaamde 'kennis-onderhoudsovereenkomsten' die worden aangeboden aan bedrijven en instellingen en 'kennisonderhoudsabonnementen' die bestemd zijn voor alumni en andere afgestudeerden in de regio.

In het kader van de kennis-onderhoudscontracten die worden afgesloten met bedrijven en instellingen biedt de Hogeschool een geïntegreerd aanbod van (post-) HBO en opleidingen op $\mathrm{MBO}+$ niveau. Deze laatste opleidingen krijgen de vorm van HBO-certificaten. Door het afsluiten van een kennis-onderhoudsovereenkomst kunnen bedrijven en instellingen een structurele relatie aangaan met de Hogeschool. Binnen het kader van deze overeenkomst schrijven zij jaarlijks medewerkers in op een van de in het 'open aanbod' te organiseren cursussen. Daarnaast geeft de overeenkomst recht op de verzorging door de Hogeschool van maatwerk-cursussen en in-company cursussen.

De afgestudeerden in het hoger onderwijs kunnen een kennis-onderhoudsabonnement afsluiten. De alumni krijgen het eerste jaar na afstuderen het kennis-onderhoudsabonnement om niet. Men verwacht dat verschillende sectoren een register van beroepsbeoefenaren zullen ontwikkelen, die de beroepsbeoefenaren verplichten tot kennisonderhoud. Een dergelijk register bestaat reeds voor de (para-)medische beroepen (de $\mathrm{BIG}$ ), en wordt - zoals in het vorige hoofdstuk reeds werd aangegeven - nu ook overwogen voor de kwaliteitsborging van leerkrachten.

Met name bij de cursussen en trainingen in het kader van het kennisonderhoud gericht op de leraren en leidinggevenden in het basisonderwijs is er behoefte aan onderwijskundigen met oog voor de pedagogische professionaliteit en de ontwikkeling van competenties van leerkrachten.

\section{Bedrijfsacademies}

Zoals in paragraaf 3.2 reeds werd aangegeven besteden bedrijven steeds meer middelen aan de scholing van hun personeel. Voor een belangrijk deel worden deze opleidingen en 
trainingen uitbesteed aan commerciële en niet-commerciële opleidingsinstellingen (zie volgende subparagraaf). Daarnaast is er echter in toenemende mate ook binnen de bedrijven sprake van een professionalisering van de bedrijfsinterne opleidingen. In diverse grote bedrijven heeft dit reeds geleid tot de vorming van zogenaamde 'bedrijfsacademies'. Deze bedrijfsacademies verzorgen gestructureerde maatwerkopleidingen die doorgaans modulair zijn opgezet. Binnen deze bedrijfsacademies is er behoefte aan onderwijskundige expertise, zowel in de staffuncties van de academies als bij het verzorgen van de opleidingen en trainingen.

De professionalisering van de interne bedrijfsopleidingen staat doorgaans in het teken van het competentiemanagement. Dit competentiemanagement wordt gevoed vanuit het besef dat door de technologische, organisatorische en marktontwikkelingen het productieproces steeds kennis-intensiever is geworden, waardoor kennis, inzicht, ervaring en het 'gedragsrepertoir' van de mensen in de organisatie bepalend zijn voor de concurrentiekracht van het bedrijf.

\section{Case: KPN Telecom}

Bij KPN Telecom vormen de voor de diverse functies binnen het bedrijf opgestelde competentieprofielen het richtinggevende kader voor het opleidingenaanbod van 'KPN Opleidingen'. Binnen de KPN worden drie soorten opleidingen onderscheiden. Het gros van de opleidingen is gericht op functie-opleidingen. Daarnaast zijn er de meer carrièregerichte loopbaan-opleidingen. Ten slotte zijn er opleidingen die door het personeel zelf worden gekozen, maar die niet altijd direct noodzakelijk zijn voor het vervullen van de huidige functie.

Binnen KPN Telecom richt het scholingsbeleid zich hoofdzakelijk op het verhogen van de opleidingskwalificaties. Momenteel volgen zo'n 2.000 medewerkers een opleiding op MBOniveau. De belangrijkste doelen zijn het verbeteren van het functioneren en het vergroten van de inzetbaarheid ('employability'). Door de sterk toegenomen concurrentie verschuift het zwaartepunt van de organisatie van techniek naar commercie. Dit maakt dat een klantgerichte houding van de medewerkers van essentieel belang wordt. De scholing van de medewerkers van het bedrijf zal in de toekomst een meer verplicht karakter krijgen en ook meer vanuit het management worden aangestuurd. Het volgen van scholing zal daarbij cruciaal worden voor de baanzekerheid. Het niet-volgen van scholing kan leiden tot gedwongen mobiliteit.

Het scholingsaanbod omvat de volledige range van het beroepsonderwijs met een LBO+ programma (voor goed functionerende werknemers waarvoor een $\mathrm{MBO}$-opleiding te hoog gegrepen is), MBO-trajecten (voor het 'opscholen' van werknemers met een LBO diploma of een verouderde $\mathrm{MBO}$-opleiding), een $\mathrm{MBO}+$ programma en een $\mathrm{HBO}+$ programma. De post-initiële scholing zal een permanent karakter hebben. 
Bij het scholingsaanbod van KPN Opleidingen wordt gebruik gemaakt van diverse ICT toepassingen. Als een werknemer kampt met kennistekorten kan hij of zij via internet of het eigen intranet de vereiste kennis in bezit krijgen. Dit zogenaamde 'kennisnet' is een open systeem waarin medewerkers de voor hun functie relevante informatie kunnen vinden (bijvoorbeeld ontwikkelingen in werksoorten e.d.). Wanneer er duidelijk meer scholing nodig is, kan er sinds kort ook via een 'leernet' gewerkt worden. Een leernet is een gesloten systeem waarin voor een bepaalde groep werknemers scholing wordt aangeboden. Een leernet maakt de communicatie tussen cursisten onderling en tussen cursisten en docenten gemakkelijk. Bovendien kan, indien gewenst, op het intranet een korte cursus, case-study of workshop worden aangeboden.

Bij KPN Opleidingen werken circa 200 mensen, waaronder een groot aantal onderwijskundigen. Deze zijn werkzaam in de rol van opleidingen-ontwerper of projectleider. Deze projectleiders zijn verantwoordelijk voor het ontwikkelen en/of uitvoeren van concrete cursussen. Vanwege de sterke opkomst van het bedrijfsinterne afstandsonderwijs is het zeer waardevol als deze onderwijskundigen over goede ICT-expertise beschikken. Overigens zal de scholing van het personeel in toenemende mate worden uitbesteed aan ROC's en commerciële aanbieders van opleidingen en trainingen waardoor een deel van de werkgelegenheid voor onderwijskundigen zal verschuiven naar andere organisaties.

\section{De open markt en trainingsmarkt}

Een groot deel van de verdere scholing van de beroepsbevolking wordt door bedrijven en intermediaire organisaties als de Arbeidsvoorzieningsorganisatie uitbesteed aan commerciële en niet-commerciële aanbieders van niet-initieel onderwijs.

In vergelijking met de Verenigde Staten is het Hoger Onderwijs in Nederland nog weinig actief als aanbieder van niet-initieel onderwijs. Eerder is reeds aangegeven hoe dit aanbod in de vorm van 'kennis-onderhoudscontracten' kan worden vergroot. De ROC's verzorgen in opdracht van de Arbeidsvoorzieningsorganisatie reeds een groot aantal opleidingen gericht op de bij- en omscholing van werkzoekenden. Daarnaast verzorgen de Hogescholen en de ROC's ook steeds vaker de zogenaamde opscholing van het personeel van bedrijven. Zo verzorgt een groot aantal ROC's de MEAO-opleiding voor de opscholing van het personeel van de RABO en de KPN. Daarnaast wordt de MBO-opleiding Telematica verzorgd voor het personeel van de KPN. Gecoördineerd door ROC De Amelanden in Amersfoort wordt op alle scholen de opleiding op dezelfde wijze vormgegeven. Dit betreft zowel de leermiddelen en lesplanning als de module-examens.

In het recentelijk door de SER uitgebrachte Advies HOOP $2000^{24}$ wordt de noodzaak van een betere marktoriëntatie van het Hoger Onderwijs sterk benadrukt. Hierbij wordt niet alleen gewezen op de taakstelling voldoende jongeren op te leiden, maar ook zorg te dragen voor het onderhouden van de kwalificaties van degenen die reeds werkzaam zijn. Hierdoor

24. SER, Advies HOOP 2000, Den Haag, 1999. 
vervaagt vanzelfsprekend de grens tussen initieel en niet-initieel onderwijs. Om een rol te kunnen vervullen in het niet-initieel onderwijs dient het Hoger Onderwijs zich zowel inhoudelijk als organisatorisch te richten op nieuwe groepen. Belangrijke aandachtspunten daarbij zijn volgens de SER:

$C$ het aanbieden van deeltijd-opleidingen;

$C$ het verder uitbouwen van het contractonderwijs;

$C$ het geven van vrijstellingen op basis van EVC's (Elders Verworven Competenties);

$C$ het vergroten van de combinatiemogelijkheden van scholing met werk en zorgtaken;

C het uitoefenen van een vraagbaakfunctie voor bedrijven en instellingen.

Met name het vergroten van de combinatiemogelijkheden van scholing met werk en zorgtaken is vanzelfsprekend een belangrijke factor voor het uitbouwen van de rol van het Hoger Onderwijs. De SER wijst daarbij op drie centrale aandachtspunten:

$C$ het vergroten van het aantal instroommomenten;

$\mathrm{C}$ het teleleren;

C het ontwikkelen van een module systeem.

Ook bij de commerciële aanbieders op de markt van niet-initieel onderwijs raken initieel en niet-initieel onderwijs, alsmede de verschillende segmenten binnen het niet-initieel onderwijs steeds meer vervlochten. Zo diversifiëren bedrijven als bijvoorbeeld het LOI, die zich traditioneel richtten op de open markt, hun opleidingen-aanbod met bedrijfstrainingen e.d. Het afstandsonderwijs (traditioneel de 'schriftelijke cursussen') en het contact-onderwijs (de 'mondelinge cursussen') raakt daarbij steeds meer vervlochten. Daarbij neem het docentonafhankelijk leren sterk in belang toe vanwege de mogelijkheden die de ontwikkelingen op ICT-gebied momenteel bieden. Daarnaast komt het contact-onderwijs steeds dichter aan te liggen tegen het door de overheid bekostigde onderwijs. In dit kader heeft het LOI bijvoorbeeld recentelijk ook een eigen Hogeschool opgericht.

Case: het $L O I$

Meer dan $75 \%$ van de bij het LOI gevolgde opleidingen is beroeps- of functiegericht. De meeste opleidingen die het LOI aanbiedt kunnen langs twee wegen worden gevolgd: via de traditionele methode of via internet: de LOI-Campus. Bij de ICT toepassingen die het LOI aanbiedt moet men echter nog terdege rekening houden met de beperkingen van de PCfiguraties waarover het merendeel van de (potentiële) gebruikers beschikt. Het is echter evident dat afstandsonderwijs bij uitstek geschikt is voor ICT toepassingen en belangrijk in ontwikkeling is. De via ICT aangeboden opleidingen hoeven zich niet te beperken tot cursussen gericht op het verwerven van cognitieve vaardigheden. Ook cursussen gericht op praktische vaardigheden of attitude-vorming lenen zich prima voor ICT toepassingen, al is het daarbij wel een vereiste dat de cursisten in staat zijn tot een bepaalde 'zelfsturing'.

Bij het LOI zijn momenteel circa 200 mensen werkzaam. Daarbij gaat het echter alleen om mensen die zich met de organisatie van cursussen, de marketing en het management 
bezig houden. De inhoudelijke deskundigheid wordt door het LOI altijd extern aangetrokken.

Hierbij gaat de voorkeur uit naar deskundigen op het specifieke vakgebied van de desbetreffende cursussen, zowel bij het samenstellen van het cursusmateriaal als bij het verzorgen van de opleiding. De vraag naar onderwijskundigen is hierbij slechts beperkt. Een belangrijke voorwaarde voor de inpassing van onderwijskundigen is dat ze voldoende vertrouwd zijn met wat er in de praktijk van een bepaald vakgebied gebeurt.

De afgelopen jaren is het certificeren van Elders Verworven Competenties (EVC's) door middel van assessments een nieuwe niet-initiële kwalificeringsactiviteit geworden. Aangenomen mag worden dat in het kader van de kwaliteitszorg deze certificeringsactiviteiten sterk zullen toenemen. Door één van de gesprekspartners wordt gewezen op de sterke opkomst van het zogenaamde 'selectie-assesment' ten behoeve van management-development, reorganisaties e.d. De 'assessoren' zijn voor het merendeel gedragspsychologen, die feedback geven op gedragscompetenties. Een veel geringer aantal heeft een pedagogische/onderwijskundige opleidingsachtergrond.

\subsection{Conclusies}

Samenvattend kan geconstateerd worden dat het belang van niet-initieel onderwijs steeds groter zal worden, enerzijds door processen van upgrading en anderzijds door een toenemende noodzaak om kwalificatie-veroudering te voorkomen. Dit belang van het niet-initieel onderwijs wordt duidelijk weerspiegeld in de toegenomen scholingsparticipatie. Daarbij komen ook nieuwe vormen op in de organisatie van 'levenslang leren', zoals de ontwikkeling van kennis-onderhoudscontracten of de ontwikkeling van bedrijfsacademies. Door deze ontwikkelingen lijkt ook de scheidslijn tussen initieel en niet-initieel onderwijs steeds meer te vervagen. Voor onderwijskundigen betekent dit dat het terrein van niet-initieel onderwijs steeds belangrijker wordt. Daarbij wordt speciale aandacht gevraagd voor het ontwerpen van opleidingen die de 'employability' van werknemers vergroten. In wezen draait het hier, net als bij geschetste ontwikkelingen in het vorige hoofdstuk, om het verwerven van sleutelkwalificaties. Daarnaast is er behoefte aan instrumenten waarmee de competenties van werknemers kunnen worden vastgesteld.

\section{Verkenning van de arbeidsmarkt voor onderwijskundigen}

\subsection{De huidige arbeidsmarktsituatie}

Gedetailleerde gegevens over de arbeidsmarkt voor onderwijskundigen zijn slechts zeer gedeeltelijk aanwezig. Weliswaar is afgelopen jaar in het kader van de WO-Monitor onderzoek verricht onder pas afgestudeerden van de universiteiten, maar in de betreffende meting ontbraken de afgestudeerden van de studierichting Toegepaste Onderwijskunde van de 
Universiteit Twente. Op een meer geaggregeerd niveau zijn wel gegevens beschikbaar, waardoor een beeld gegeven kan worden van de bredere arbeidsmarktcontext waarbinnen onderwijskundigen functioneren.

De arbeidsmarkt voor hoger opgeleiden is in snel tempo verbeterd. In de recent door het ROA uitgebrachte rapportage over de arbeidsmarktpositie van schoolverlaters wordt geconstateerd dat de arbeidsmarkt voor pas afgestudeerden zeer krap is. De werkloosheid onder afgestudeerden van het WO uit het studiejaar 1997-1998 bedraagt anderhalf jaar na afstuderen slechts $3 \%$, en bij het HBO eveneens $3 \%^{25}$. Voor de afgestudeerden van de opleidingen onderwijskunde en pedagogiek is dit beeld niet anders. De werkloosheid voor beide studierichtingen samen bedraagt eveneens 3\%. De gunstige arbeidsmarkt voor hoger opgeleiden blijkt niet alleen uit de lage werkloosheid, maar ook uit de stijging van het aantal vaste aanstellingen. Hoewel trendcijfers over het WO ontbreken, blijkt uit de overige schoolverlatersonderzoeken dat de flexibiliseringstendens van begin jaren negentig is omgeslagen. Had vorig jaar nog $25 \%$ van de schoolverlaters een tijdelijke aanstelling, dit jaar bedraagt dit nog maar $18 \%$. Daarnaast blijken de aanvangssalarissen explosief gestegen te zijn. Voor afgestudeerden van het HBO bedroeg de stijging zo'n $10 \%{ }^{26}$. Geconcludeerd wordt dat voor vrijwel alle sectoren in het hoger onderwijs de arbeidsmarkt zeer gespannen is.

De totale omvang van het werkveld voor onderwijskundigen is niet precies aan te geven. Dit komt enerzijds omdat afgestudeerde onderwijskundigen in meerdere beroepen werkzaam kunnen zijn en anderzijds omdat binnen onderwijskundige beroepen ook mensen met een andere opleidingsachtergrond werkzaam zijn. Op basis van de Enquête Beroepsbevolking kan wel een schatting gemaakt worden van de totale omvang van de beroepsgroep 'onderwijskundigen en pedagogen'27. Deze beroepsgroep omvat onderwijskundige en pedagogische beroepen op academisch niveau, zoals beleidsmedewerker onderwijs, onderwijskundig onderzoeker of orthopedagoog. Het gemiddelde aantal werkenden in deze beroepsgroep bedroeg in de periode 1995-1996 20.500 personen (in f.t.e. 17.500). De hieraan verwante beroepsgroep op HBO-niveau omvat 8.500 personen (in f.t.e. 7.500). Deze beroepsgroep van 'onderwijskundig medewerkers' omvat beroepen als schoolbegeleider of onderwijskundig medewerker. Het is van belang om op te merken dat uiteraard slechts een deel van de werkenden in deze twee beroepsgroepen een onderwijskundige achtergrond heeft. Zo heeft een kwart van de werkenden in de beroepsgroep 'onderwijskundigen en pedagogen' een opleiding op HBO-niveau gedaan (bijvoorbeeld de lerarenopleiding). En van degenen met een academische achtergrond heeft uiteraard slechts een deel onderwijskunde gestudeerd. Daar staat tegenover dat afgestudeerde onderwijskundigen ook in andere beroepsgroepen dan de twee bovengenoemde terechtkomen. Ter indicatie: van de pas afgestudeerde onderwijskundigen is ongeveer de helft in één van de beide genoemde beroepsgroepen werkzaam, terwijl de overigen verspreid zijn over andere beroepsgroepen.

25. ROA, Schoolverlaters tussen onderwijs en arbeidsmarkt 1998, ROA-R-1999/5, Maastricht, 1999.

26. J. Allen en G. Ramaekers, De arbeidsmarktpositie van afgestudeerden van het hoger beroepsonderwijs 1998, HBO-Raad, Den Haag, 1999.

27. ROA, De arbeidsmarkt naar opleiding en beroep tot 2002, ROA-R-1997/7, Maastricht, 1997. 
Driekwart van de afgestudeerden geeft overigens aan dat voor de functie de eigen of een verwante studierichting werd vereist, hetgeen impliceert dat ook buiten de twee genoemde beroepsgroepen er functies bestaan waarvoor een onderwijskundige of verwante opleiding vereist is.

De werkvelden waarin onderwijskundigen terecht komen zijn divers. Een traditioneel belangrijk werkveld voor onderwijskundigen zijn de regionale en plaatselijke Schoolbegeleidingsdiensten (SBD's) waar naar schatting zo'n 2.500 tot 3.000 mensen werkzaam zijn. Voor een belangrijk deel betreft dit oud-leerkrachten die, nadat ze zelf in het onderwijs hebben gewerkt, doorgestroomd zijn naar een functie als schoolbegeleider. Vaak heeft men daartoe een deeltijdopleiding onderwijskunde gevolgd. Daarnaast zijn bij de SBD's veel orthopedagogen werkzaam. De onderwijskundigen houden zich vooral bezig met systeembegeleiding, de orthopedagogen vooral met de individuele begeleiding van leerlingen. Verwacht kan worden dat als gevolg van de bestuurlijke schaalvergroting (zie paragraaf 2.1) een deel van de werkgelegenheid zal verschuiven van de SBD's naar de onderwijsinstellingen zelf. Anderzijds zullen ook nieuwe taken ontstaan in het kader van zorgverbreding (Weer Samen Naar School, de invoering van leerwegondersteunend onderwijs).

Een ander belangrijk werkterrein voor onderwijskundigen omvat de landelijke pedagogische centra en instellingen als CITO, CINOP en SLO. Hier werken zo'n 400 mensen, waarvan een belangrijk deel een onderwijskundige achtergrond heeft. De onderwijskundigen die hier werkzaam zijn houden zich met name bezig met curriculumontwikkeling, toetsontwikkeling en onderwijsondersteuning. Daarnaast worden ook bij de Landelijke Organen Beroepsonderwijs (LOB's) steeds meer onderwijskundigen aangetrokken voor de onderwijsontwikkeling. Gelet op de in hoofdstuk 2 geschetste ontwikkelingen in het initieel onderwijs kan verwacht worden dat de werkgelegenheid bij dit type instellingen verder zal toenemen.

De werkgelegenheid voor onderwijskundigen bij de educatieve uitgeverijen lijkt op dit moment nog vrij beperkt te zijn. Weliswaar zijn bij de educatieve uitgeverijen soms onderwijskundigen werkzaam als fondsbeheerder, maar men werft niet speciaal onder onderwijskundigen. Voor de ontwikkeling van lesmateriaal doet men in de regel een beroep op mensen van buiten. Vaak zijn dat vakdocenten uit het middelbaar onderwijs of vakdidactici verbonden aan universiteiten of hogescholen. De ontwikkeling van nieuwe lesmaterialen is meestal een nevenactiviteit van mensen die reeds een aanstelling in het onderwijs of elders hebben. Verwacht wordt overigens dat de vraag naar onderwijskundigen in deze sector zal gaan toenemen, met name voor de ontwikkeling van nieuwe leermaterialen en educatieve software.

Een belangrijk nieuw terrein voor onderwijskundigen is gerelateerd aan het niet-initieel onderwijs. De groei van bedrijfsopleidingen heeft ertoe geleid dat meer en meer onderwijskundigen werkzaam zijn bij bedrijven of trainingsinstituten en intermediaire organisaties (sectorale $O \& O$ fondsen e.d.). Door het toenemend belang van 'levenslang leren' en de daaraan gekoppelde scholingsparticipatie zal dit werkterrein in de toekomst nog aan belang 
toenemen. Wellicht zal ook op sectoraal niveau meer werkgelegenheid ontstaan, bijvoorbeeld bij de sectorale O\&O fondsen die zich met scholingsvraagstukken bezig houden.

De werkgelegenheid bij onderwijsinstellingen zelf is in hoofdzaak beperkt tot $R O C$ 's en de instellingen voor hoger onderwijs. Bij de meeste ROC's is een stafafdeling aanwezig waar enkele onderwijskundigen werkzaam zijn. Hetzelfde geldt voor instellingen voor hoger onderwijs, alhoewel daar een belangrijk deel van de onderwijsontwikkeling ook plaats vindt door de vakdocenten zelf. Daarnaast zijn onderwijskundigen werkzaam bij de PABO's en lerarenopleidingen, bij sociaal wetenschappelijke onderzoeksinstituten en uiteraard bij de vakgroepen voor onderwijskunde. Verwacht wordt dat met name bij de PABO's en lerarenopleidingen meer behoefte zal ontstaan aan onderwijskundigen. Binnen de onderzoeksinstituten wordt een verschuiving van het werkterrein verwacht, waarbij er meer aandacht zal komen voor onderzoek op het terrein van onderwijs en $\mathrm{ICT}^{28}$.

Ten slotte zijn onderwijskundigen werkzaam bij beleidsinstanties als ministeries, provincies en gemeenten. Vooral bij de grotere gemeenten heeft een groei plaats gevonden van de werkgelegenheid voor onderwijskundigen. Er zijn geen indicaties dat de werkgelegenheid bij de beleidsinstanties nog verder zal groeien.

\subsection{Toekomstige ontwikkelingen}

Uit de arbeidsmarktprognoses van het ROA komt naar voren dat de arbeidsmarktperspectieven voor hoger opgeleiden zowel op de middellange termijn (2002) als op de wat langere termijn (2007) goed tot zeer goed zijn ${ }^{29}$. Dit geldt ook voor het opleidingstype sociale wetenschappen, waartoe ook de opleidingen pedagogiek en onderwijskunde worden gerekend. Voor dit opleidingstypen worden de verwachte arbeidsmarktperspectieven op de middellange termijn als 'goed' getypeerd. De prognoses zijn niet verder verbijzonderd naar opleiding. Wel wordt bij deze prognoses een indicatie gegeven van het verwachte aantal 'baanopeningen'30 voor de pedagogische beroepen. Voor de eerder genoemde beroepsgroep 'onderwijskundigen en pedagogen' bedraagt het totaal aantal banen dat in de periode 19972002 vrijkomt voor nieuwkomers op de arbeidsmarkt 6.000, dat wil zeggen gemiddeld 1.200 per jaar. De helft hiervan ontstaat door uitbreiding van de werkgelegenheid en de andere helft door vervanging wegens pensionering of het om andere redenen al dan niet tijdelijk terugtrekken van de arbeidsmarkt. Op het totaal aantal werkenden in de beroepsgroep bedraagt het jaarlijkse percentage baanopeningen $5.4 \%$, hetgeen als 'gemiddeld' kan worden gekarakteriseerd. Voor de beroepsgroep 'onderwijskundig medewerkers' (dit betreft zoals

28. Zie P. van den Dool, c.s, cp.cit.

29. Zie respectievelijk ROA, De arbeidsmarkt naar opleiding en beroep tot 2002, ROA-R-1997/7, Maastricht, 1997 en L. Borghans cs., Toekomstverkenning arbeidsmarkt en scholing tot 2007, Ministerie van Sociale Zaken en Werkgelegenheid, Den Haag, 1998.

30. Met baanopeningen wordt bedoeld de banen die vrijkomen voor nieuwkomers op de arbeidsmarkt, hetzij als gevolg van een groei van de werkgelegenheid ('uitbreidingsvraag') hetzij als vervanging voor personeel dat uittreedt ('vervangingsvraag'). 
eerder aangegeven de onderwijskundige beroepen op HBO-niveau) bedraagt het totaal aantal baanopeningen in de periode 1997-2002 naar verwachting ruim 5.000, hetgeen overeenkomt met een jaarlijks percentage van 10\%. Dit percentage kan als 'erg hoog' worden getypeerd. Nogmaals zij opgemerkt dat slechts een deel van deze baanopeningen bestemd is voor mensen met een onderwijskundige opleidingsachtergrond. Niettemin lijkt de conclusie gerechtvaardigd dat de totale werkgelegenheid voor onderwijskundigen zal uitbreiden. Daarnaast is er een vraag naar onderwijskundigen ten gevolge van pensionering en vervroegde uittreding.

Om een schets te kunnen geven van de toekomstige arbeidsmarkt voor onderwijskundigen is het nodig om de verwachte vraag naar onderwijskundigen te confronteren met de verwachte arbeidsmarktinstroom van afgestudeerde onderwijskundigen. Specifieke prognoses hierover kunnen ontleend worden aan de WO Verdeelraming 1998 van de Directie Wetenschappelijk Onderwijs van het Ministerie van Onderwijs, Cultuur en Wetenschappen. Deze geven een raming van de instroom in het eerste jaar voor de verschillende studierichtingen alsmede een raming van het verwachte aantal behaalde doctoraal-diploma's. In de Verdeelraming wordt een onderscheid gemaakt tussen de studierichtingen 'Pedagogiek/ Andragogiek' en 'Toegepaste Onderwijskunde'. De laatstgenoemde studierichting heeft alleen betrekking op de studie onderwijskunde aan de Universiteit Twente. Voor de overige universiteiten is de raming van het aantal eerstejaars en het aantal doctoraal-diploma's opgenomen binnen de categorie 'Pedagogiek/Andragogiek'. Op grond van de uitstroomgegevens van deze overige universiteiten uit het jaar 1995/1996 kan worden opgemaakt dat ongeveer $20 \%$ van de uitstroom van 'Pedagogiek/Andragogiek' een diploma onderwijskunde heeft behaald. Op grond hiervan is een indicatieve schatting gemaakt van in- en uitstroom bij de studies onderwijskunde (zie bijlage 2). De cijfers laten zien dat zowel de instroom in de opleiding (het aantal eerstejaars) als de uitstroom van de opleiding een dalende tendens vertoont. Het aantal eerstejaars is met name tussen 1993 en 1994 sterk afgenomen. Vanaf 1996 loopt de instroom langzaam terug van 255 eerstejaars naar 228 in $2002^{31}$. Wat betreft de uitstroom van gediplomeerden wordt verwacht dat deze zal teruglopen van 220 in 1996 tot 161 in 2002.

Hoewel het aantal baanopeningen in de twee onderscheiden beroepsgroepen voor onderwijskundigen en de ontwikkeling in het aantal afgestudeerden niet direct met elkaar vergeleken mogen worden, zijn de tendenties duidelijk. Gelet op de verwachte stijging van de werkgelegenheid in een aantal relevante beroepsgroepen, de verwachte daling in het aantal gediplomeerde onderwijskundigen en de in het algemeen als goed getypeerde arbeidsmarktsituatie voor social wetenschappers kan geconcludeerd worden dat naar verwachting op de middellange termijn aanzienlijke tekorten in dit arbeidsmarktsegment verwacht kunnen worden. In die context kan het starten van een nieuwe opleiding onderwijswetenschappen een bijdrage leveren aan het verminderen van de toekomstige tekorten aan onderwijskundigen.

31. Hierbij zijn inbegrepen de studenten die na een gemeenschappelijke propedeuse pedagogiek/ andragogiek onderwijskunde kiezen. 


\section{Het perspectief van een nieuwe opleiding onderwijskunde}

In de voorgaande hoofdstukken is een aantal ontwikkelingen geschetst in het initieel en nietinitieel onderwijs die belangrijke gevolgen hebben voor de vraag naar onderwijskundigen. Gemeenschappelijke elementen hierin zijn:

$C$ een verschuiving van een leerstofgerichte benadering naar een benadering waarin de competenties van leerlingen centraal staan;

C een veranderende rol van de docent van leider naar begeleider van onderwijsprocessen;

$C$ een sterkere gerichtheid op de beroepspraktijk met nadrukkelijke aandacht voor sleutelkwalificaties;

C toenemende flexibiliteit, differentiatie en maatwerk in het onderwijsleerproces;

C een toenemend belang van ICT in het onderwijsleerproces;

C toenemende professionalisering van de beroepsgroep van leerkrachten;

$C$ toenemend belang van levenslang leren en een hiermee samenhangende groei van de scholingsparticipatie.

De bovengenoemde ontwikkelingen doen naar verwachting een groot beroep op onderwijskundige ondersteuning. Belangrijke competenties waarover onderwijskundigen moeten beschikken zijn:

C in staat zijn leerpsychologische modellen te hanteren gericht op competentie-ontwikkeling;

C in staat zijn nieuwe didactische concepten toe te passen in onderwijsleersituaties;

C in staat zijn om ICT toe te passen in een didactisch concept;

$C$ in staat zijn opleidingen te ontwerpen voor de beroepspraktijk, zowel binnen als buiten schoolverband;

C in staat zijn toetsen te ontwerpen voor het meten van (domeinspecifieke) competenties;

$C$ in staat zijn om scholingsvraagstukken te plaatsen binnen een bredere organisatorische context en in staat zijn om onderwijskundige oplossingen te implementeren.

De huidige arbeidsmarkt voor onderwijskundigen is, zoals in hoofdstuk 4 werd aangegeven, net als voor de meeste andere sectoren in het hoger onderwijs, bijzonder gunstig. De werkloosheid onder pas afgestudeerden bedraagt slechts 3\%. Verwacht wordt dat in de nabije toekomst de vraag naar afgestudeerden nog verder zal toenemen. Tegelijkertijd kampen de opleidingen voor onderwijskunde en pedagogiek met een teruglopend aantal afgestudeerden. Gelet op de relatief hoge vraag in de pedagogische beroepen zullen hierdoor aanzienlijke knelpunten in de personeelsvoorziening kunnen gaan ontstaan.

Vanuit deze optiek is het erg belangrijk de toekomstige arbeidsmarktinstroom van onderwijskundigen te stimuleren. Om meer studenten voor een bepaalde studierichting te interesseren kan, afgezien van arbeidsmarktprikkels (relatieve beloning, loopbaanmogelijkheden, e.d.), een drietal wegen worden gevolgd:

$C$ het vergroten van het aantal opleidingsplaatsen voor onderwijskunde;

C het aanbieden van een ander opleidingsprofiel naast de bestaande profielen;

C het verbreden van de doelgroep voor de opleiding. 
Het is uiteraard niet precies mogelijk om te voorspellen wat het effect zal zijn op de totale instroom van onderwijskundigen wanneer in Maastricht een nieuwe opleiding zou worden gestart. Een indicatie kan echter verkregen worden door te kijken naar de instroomontwikkeling bij de studierichting psychologie. Zoals bekend is in 1995 een nieuwe opleiding psychologie gestart in Maastricht. Uit de WO Verdeelraming 1998 kan ontleend worden hoe de instroom in de studierichting psychologie zich in de periode 1992-1997 ontwikkeld heeft en wat de ramingen zijn voor de periode tot 2002. In bijlage 3 is weergegeven hoe het aantal eerstejaars psychologie zich ontwikkeld heeft, zowel in Maastricht als bij de overige universiteiten. Omdat het absolute aantal eerste jaar ook afhankelijk is van demografische factoren is tevens het relatieve aandeel eerstejaars psychologie in het totaal aantal eerstejaars in het WO weergegeven. Uit de cijfers komt naar voren dat het starten van de nieuwe opleiding in Maastricht niet of nauwelijks geleid heeft tot een daling van het aantal eerstejaars bij de overige universiteiten. Integendeel, de gegevens wijzen er op dat de relatieve belangstelling voor psychologie duidelijk is toegenomen. $\mathrm{Na}$ een aanvankelijke daling van $6,3 \%$ in 1992 naar $5,5 \%$ in 1994, neemt de belangstelling vanaf 1995 weer toe naar een geraamde 7,0\% van de totale studenteninstroom in het wetenschappelijk onderwijs in 2002.

Het lijkt er daarom op dat door het aanbieden van een nieuwe opleiding Onderwijswetenschappen de totale belangstelling voor de betreffende studierichting vergroot kan worden. Dit kan zowel te maken hebben met de regionale factor als met een andere profilering van de opleiding. Overigens kan de vergrote instroom in de studie onderwijskunde wel ten koste gaan van andere studierichtingen, bijvoorbeeld van de huidige studierichting psychologie in Maastricht.

Met de nieuwe opleiding kan ook expliciet getracht worden de doelgroep voor de betreffende studierichting te vergroten, bijvoorbeeld door zich te richten op buitenlandse studenten (door het aanbieden van een internationale opleiding), of degenen die nu reeds werkzaam zijn (door het aanbieden van deeltijdopleidingen, afstandsonderwijs, e.d.). In het recente SER Advies HOOP 2000 wordt met name ook gewezen op het maatschappelijk belang van het aantrekken van nieuwe doelgroepen voor het Hoger Onderwijs.

De voorgestelde opleiding Onderwijswetenschappen kan tegen deze achtergrond beschouwd worden als een belangrijk instrument om in de toekomstige vraag naar onderwijskundigen te voorzien. Het starten van een nieuwe opleiding in Maastricht met een eigen opleidingsprofiel zal naar verwachting de totale instroom van studenten onderwijskunde in Nederland vergroten en daarmee een bijdrage leveren aan het verminderen van de tekorten aan onderwijskundigen.

Ook het profiel van de nieuwe studie lijkt in zijn algemeenheid goed te passen bij de geschetste ontwikkelingen, met name waar het de competentiegerichte benadering en de invoering van ICT betreft. In de gesprekken met deskundigen werd dan ook in het algemeen het belang van een nieuwe opleiding onderwijskunde onderschreven. Als sterke punten van de voorgestelde opleiding kunnen worden beschouwd: 
C het probleem-gestuurd onderwijs;

C de competentiegerichte benadering;

C de gerichtheid op de professionele praktijk.

Waar de probleemgestuurde benadering in het onderwijs steeds belangrijker wordt, dient juist in een opleiding onderwijskunde dit principe ook krachtig gehanteerd te worden. Door PGO leren studenten te reflecteren over hun eigen leerproces. Voor toekomstige onderwijskundigen is dit bij uitstek van belang omdat dit hun object van studie betreft. De UM heeft een erkende expertise op dit terrein en een opleiding onderwijskunde lijkt daarmee organisch goed te passen binnen deze universiteit.

Ook de competentiegerichte benadering van de nieuwe opleiding en de gerichtheid op de professionele praktijk sporen goed met de eerder geschetste ontwikkelingen in het veld. Met name de afstudeerrichting Continu Leren voor en in de Professionele Praktijk lijkt goed te passen bij deze ontwikkelingen. In de interviews is aangeven dat afgestudeerden van een dergelijke opleiding een bijdrage moeten kunnen leveren aan de ontwikkeling van een nieuw leerpsychologisch model, waarbij de verwerving van competenties voor een professionele praktijk centraal staat. De studenten moeten instrumenten kunnen ontwerpen om deze competenties te meten (assessment), alsmede leerplannen kunnen ontwerpen om tot verder expertise-ontwikkeling te komen. Het is erg belangrijk dat dit niet beperkt wordt tot ontwerpvaardigheden sec, maar dat men ook leert hoe een dergelijk ontwerp ingebed kan worden in de organisatie. Daarom dient in de opleiding ook voldoende aandacht geschonken te worden aan implementatievraagstukken, bijvoorbeeld de implementatie van scholing binnen de arbeidsorganisatie en organisatievraagstukken (bedrijfseconomische kennis).

Een belangrijke doelgroep in dit verband kan gevormd worden door de professionals in het onderwijs zelf, zowel wat betreft de potentiële instroom voor de opleiding als wat betreft het object van studie in de opleiding. De studie onderwijskunde geldt van oudsher als een belangrijke doorstroomopleiding voor degenen die in het onderwijs werkzaam zijn geweest. Met name via het aanbieden van deeltijdvarianten zou deze doelgroep verder bediend kunnen worden. Daarnaast vormt de professionele ontwikkeling van leerkrachten een belangrijk object van studie in de opleiding zelf. Daarbij gaat het om vraagstukken als: hoe verloopt de ontwikkeling van novice tot expert, over welke competenties dienen beginnende leerkrachten te beschikken, op welke wijze kunnen die worden vastgesteld en hoe kunnen individuele opleidingstrajecten ontworpen worden om deficiënties weg te werken? Cases voor de bestudering van deze vraagstukken zouden bij uitstek ontleend kunnen worden aan de professionele beroepspraktijk van leerkrachten. Voor degenen die afkomstig zijn uit het onderwijs zelf biedt dit bovendien een goede reflectie op het eigen beroepsmatig functioneren.

De nieuwe opleiding kan zich daarom onderscheiden door het proces van professionalisering van de beroepsgroep van leerkrachten te begeleiden. Ook de ICT component in de opleiding zou gebruikt kunnen worden ten behoeve van de ondersteuning van de professionele netwerken. Daarbij kan het zowel gaan om het ontwerpen van expertsystemen op het gebied 
van het onderwijsleerproces, als om de bevordering van de communicatie binnen de beroepsgroep. Ook het aspect van kennismanagement zou daarbij voldoende aan bod moeten komen.

Door verschillende gesprekspartners is aangegeven dat een strikt onderscheid tussen enerzijds Continu Leren voor en in de Professionele Praktijk en anderzijds Leren en Elektronische Leeromgevingen minder wenselijk is. Vraagstukken rond onderwijs- en informatietechnologie zijn immers bij uitstek relevant voor het ontwerp van opleidingen voor de professionele praktijk zelf. Binnen de afstudeerrichting dient daarom voldoende aandacht besteed te worden aan de betekenis van ICT voor het onderwijsleerproces.

Bij de afstudeerrichting Leren en Elektronische Leeromgevingen zou een te sterke focus op de ICT als oplossing voor scholingsvraagstukken vermeden moeten worden. Het gaat hier immers niet alleen om een ontwerpactiviteit, maar juist ook om de inbedding ervan in de organisatie en om het ontwikkelen van een passend didactisch concept. Ook dit vereist een interdisciplinaire benadering, waarbij scholingsvraagstukken vanuit een bredere optiek worden geanalyseerd. Daarbij dient voldoende aandacht geschonken te worden aan organisatievraagstukken en kennismanagement.

Door één van de gesprekspartners is aangegeven dat het werkterrein van onderwijs en technologie gedefinieerd kan worden als het snijvlak van onderwijspsychologie (met de nadruk op cognitieve en instructiepsychologie), kennistechnologie en informatietechnologie. Het is belangrijk om op het snijvlak van die drie disciplines met een nieuw profiel te komen. Belangrijk daarbij is een daadwerkelijk interdisciplinaire benadering. De opleiding in Maastricht zou zich op dit punt met name sterk kunnen profileren door een verbinding te leggen met onderwijspsychologie en kennistechnologie. 


\section{Bijlage 1 Lijst van gesprekspartners}

D. Adema, HBO-Raad

Mevr. A. Bosscha, Groep Educatieve Uitgeverijen van het Nederlands Uitgeversverbond

J. van Dam, KPN Opleidingen

P. van den Dool, Onderwijsinspectie

J. Hameling, BVE Raad

J. Kok, procesmanagement primair onderwijs

M. Kuipers, LOI

E. van Loon, Assessment \& Development (ADC)

J. van Oppen, Ichtus Academie

K. Visser, CINOP

Mevr. C. Visscher 't Hooft, procesmanagement voortgezet onderwijs

Mevr. S. Walvisch, directie Arbeidsvoorwaarden en Beroepskwaliteit van ministerie van Onderwijs, Cultuur en Wetenschappen

Aan de geselecteerde deskundigen is van te voren een notitie toegezonden waarin de achtergrond van het onderzoek is aangegeven en de aandachtspunten worden aangegeven waarover we nadere informatie willen hebben. 
Bijlage 2 Geschatte ontwikkeling van de instroom en uitstroom bij onderwijskunde in de periode 1993-2002

\begin{tabular}{lll} 
Jaar & Instroom & Uitstroom \\
& & \\
\hline & & \\
1993 & 277 & 218 \\
1994 & 326 & 240 \\
1995 & 280 & 268 \\
1996 & 255 & 220 \\
1997 & 253 & 207 \\
1998 & 250 & 192 \\
1999 & 245 & 177 \\
2000 & 237 & 166 \\
2001 & 233 & 164 \\
2002 & 228 & 161 \\
\hline
\end{tabular}

Bron: WO Verdeelraming 1998, eigen berekeningen 


\section{Bijlage 3 Ontwikkeling aantal eerstejaars psychologie}

\begin{tabular}{|c|c|c|c|c|}
\hline Jaar & Maastricht & rest Nederland & $\begin{array}{c}\text { totaal } \\
\text { psychologie }\end{array}$ & $\begin{array}{c}\text { aandeel } \\
\text { psychologie }\end{array}$ \\
\hline & & in totaal & & instroom WO \\
\hline 1992 & 0 & 2124 & 2124 & $6,3 \%$ \\
\hline 1993 & 0 & 1975 & 1975 & $6,0 \%$ \\
\hline 1994 & 0 & 1758 & 1758 & $5,5 \%$ \\
\hline 1995 & 93 & 1528 & 1621 & $5,7 \%$ \\
\hline 1996 & 141 & 1700 & 1841 & $6,6 \%$ \\
\hline 1997 & 182 & 1806 & 1988 & $6,8 \%$ \\
\hline 1998 & 218 & 1785 & 2003 & $6,8 \%$ \\
\hline 1999 & 261 & 1776 & 2037 & $6,9 \%$ \\
\hline 2000 & 274 & 1735 & 2009 & $7,0 \%$ \\
\hline 2001 & 275 & 1731 & 2006 & $7,0 \%$ \\
\hline 2002 & 288 & 1715 & 2003 & $7,0 \%$ \\
\hline
\end{tabular}

Bron: WO Verdeelraming 1998

Periode 1992-1997 gebaseerd op CBS-tellingen; periode 1998-2002 prognose OC\&W 
